\title{
CAMILLA BRORUPDNSSEGAAR
}

JESPER DE'HEMTMEGEBERG KASPER STEENBERG

NERIMAN TIFTKCI $=1 \%$

STINNA VESTIERAARD,

FoRSKNM GSKORIIITENING

MA HANDJUERBAREEFORHOLD

TIN GAYN FOR FASTHOLDELSE,

OSG IPTAG OG FORBEDREDE

RESULAIIR I ERR N VERVSUD-

DANAELSET⿱N口,

DANSK CLEARINGHOUSE FOR UDDANNELSESFORSKNING 20074
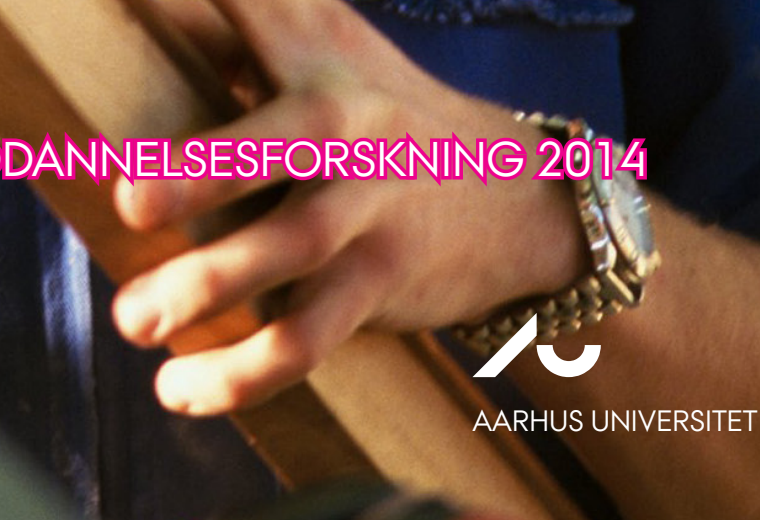

Camilla Brørup Dyssegaard, Jesper de Hemmer Egeberg, Kasper Steenberg, Neriman Tiftikci og Stinna Vestergaard

\section{Forskningskortlægning af}

\section{håndterbare forhold til gavn for}

fastholdelse, øget optag og

forbedrede resultater $i$

erhvervsuddannelserne

Dansk Clearinghouse for Uddannelsesforskning Institut for Uddannelse og Pædagogik (DPU)

Aarhus Universitet (2014) 
Dansk Clearinghouse for Uddannelsesforskning

er en enhed ved Aarhus Universitet

Titel Forskningskortlægning af håndterbare forhold til gavn for fastholdelse, øget optag og forbedrede resultater i erhvervsuddannelserne

Copyright $\quad$ C 2014 by Danish Clearinghouse for Educational Research

ISBN

$978-87-7684-866-8$

Sektion

Teknisk Rapport

Reviewgruppe Lektor Vibe Aarkrog, IUP, Aarhus Universitet

Clearinghouse Postdoc Camilla Brørup Dyssegaard, leder

Videnskabelige assistenter:

Jesper de Hemmer Egeberg

Kasper Steenberg

Neriman Tiftikci

Stinna Vestergaard

Projektnummer

15153

Publikationsmåned Januar 2014

og år

Denne rapport

Dyssegaard, C.B., de Hemmer Egeberg, J., Steenberg, K., Tiftikci, N. \&

citeres som

Vestergaard, S. (2014)

Forskningskortlægning af håndterbare forhold til gavn for fastholdelse, øget optag og forbedrede resultater i erhvervsuddannelserne. København: Institut for Uddannelse og Pædagogik, Aarhus Universitet.

Kontaktadresse

Dansk Clearinghouse for Uddannelsesforskning

Aarhus Universitet

Tuborgvej 164

2400 København NV

Telefon: +4587163942

cbd@dpu.dk

http//:edu.au.dk/forskning/omraader/danskclearinghouseforuddannelsesforskning 


\section{Indhold}

FORORD

SAMMENFATNING

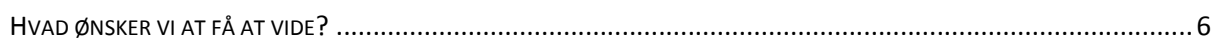

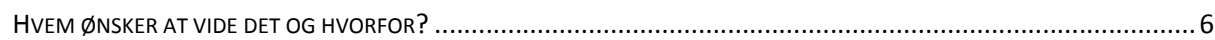

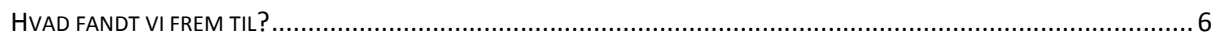

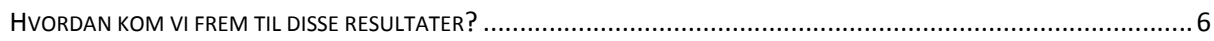

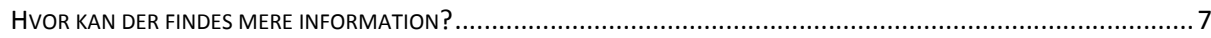

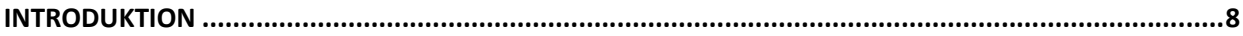

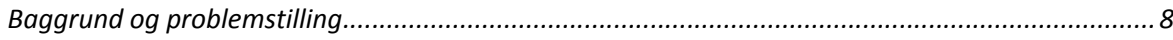

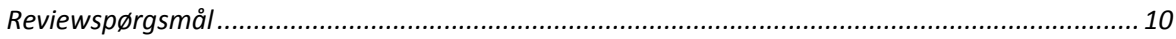

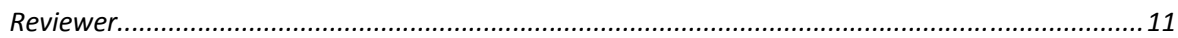

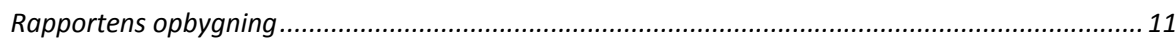

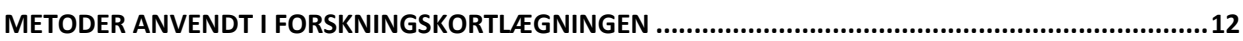

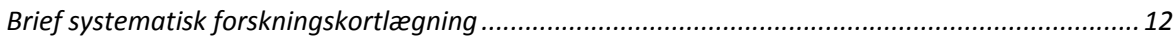

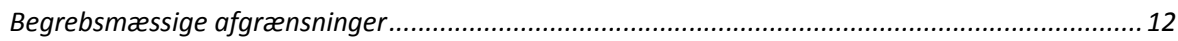

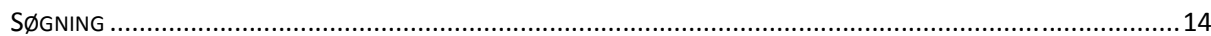

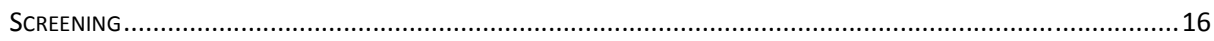

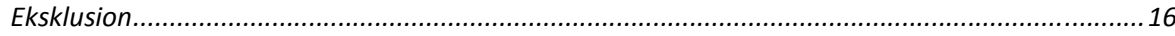

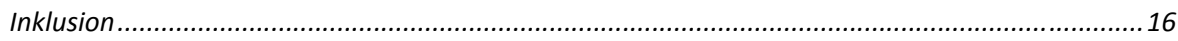

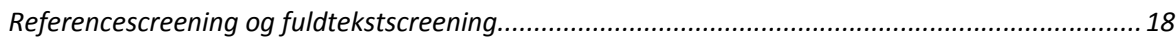

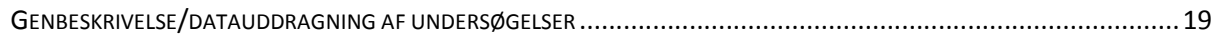

HÅNDTERBARE FORHOLD TIL GAVN FOR FASTHOLDELSE, ØGET OPTAG OG FORBEDREDE RESULTATER I

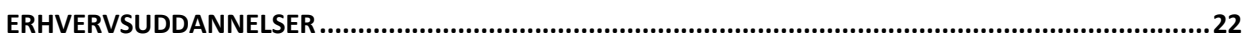

MOTIVATIONSFAKTORER FOR ELEVER PÅ ERHVERVSUDDANNELSER...............................................................22

Sammenfatning vedrørende studier rettet mod motivationsfaktorer for elever på

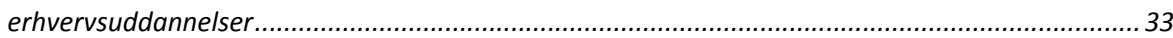

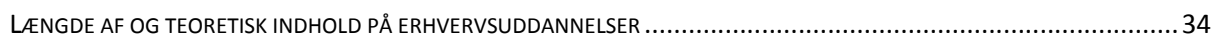

Sammenfatning vedrørende længde af og teoretisk indhold på erhvervsuddannelser ......................39

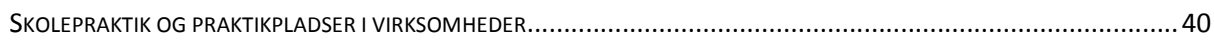

Sammenfatning vedrørende skolepraktik og praktikpladser i virksomheder .................................49

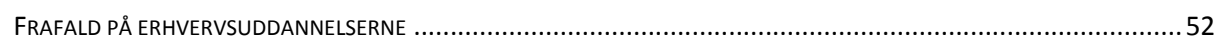

Sammenfatning vedrørende frafald på erhvervsuddannelser ......................................................69

OPSUMMERING 


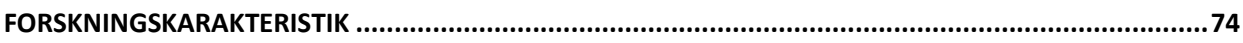

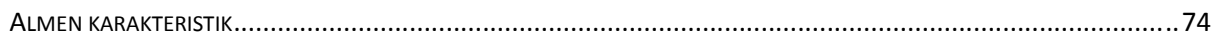

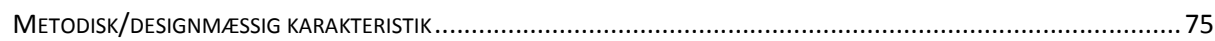

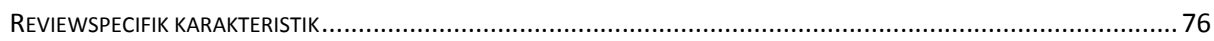

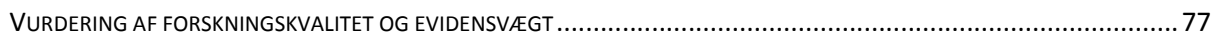

LITTERATURLISTE

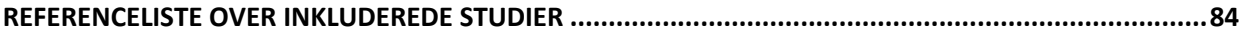




\section{Forord}

Hermed udgives denne systematiske forskningskortlægning af håndterbare forhold til gavn for fastholdelse, øget optag og forbedrede resultater i erhvervsuddannelserne. Projektet er gennemført ved Dansk Clearinghouse for Uddannelsesforskning, Aarhus Universitet. Opdragsgiver har været Tænketanken DEA. Projektet er gennemført i perioden 1. september 2013 til 1. februar 2014.

Dansk Clearinghouse for Uddannelsesforskning ønsker at takke Tænketanken $D E A$ for den tildelte opgave.

Camilla Brørup Dyssegaard

København 01.02.2014 


\section{Sammenfatning}

\section{Hvad ønsker vi at få at vide?}

Hvad kan få unge til at søge ind på en erhvervsuddannelse? Hvilke politisk håndterbare forhold kan, via en målrettet indsats, gøre en forskel i forhold til elevfrafald og elevudbytte i erhvervsuddannelserne?

\section{Hvem ønsker at vide det og hvorfor?}

Opdragsgiver er Tænketanken DEA, der har nedsat en ungdomsuddannelseskommission, som skal komme med forslag til en reform af de danske ungdomsuddannelser.

\section{Hvad fandt vi frem til?}

Vi fandt i alt 36 studier, der lever op til kortlægningens inklusionskriterier. Studierne er publiceret i form af 41 referencer fra år 2005 ff. Studierne har undersøgt håndterbare forhold til gavn for fastholdelse, øget optag og forbedrede resultater i erhvervsuddannelserne. 27 af disse studier blev vurderet til at være af medium eller høj forskningskvalitet.

\section{Hvordan kom vi frem til disse resultater?}

Forskningskortlægningen er gennemført på det grundlag, der er beskrevet i Dansk Clearinghouse for Uddannelsesforsknings Konceptnotat samt Notat om forskningskvalitet.

Den er skabt ved et gennemløb af en række trin og processer på eksplicit og transparent vis. Dansk Clearinghouse for Uddannelsesforskning har valgt i denne sammenhæng at anvende særligt software til arbejdet, EPPI-Reviewer. 


\section{Hvor kan der findes mere information?}

På Dansk Clearinghouse for Uddannelsesforsknings hjemmeside kan man finde et link til det forskningsgrundlag, Konceptnotat samt Notat om forskningskvalitet, som styrer forskningsprocessen i Dansk Clearinghouse for Uddannelsesforskning:

http://edu.au.dk/forskning/omraader/danskclearinghouseforuddannelsesforskning/ http://edu.au.dk/fileadmin/www.dpu.dk/omdpu/danskclearinghouseforuddannelesesfors kning/udgivelser/

Notat_om_Forskningskvalitet_15.11.12.pdf 


\section{Introduktion}

\section{Baggrund og problemstilling}

Denne rapport er udformet på baggrund af en kontrakt mellem Tænketanken DEA og Dansk Clearinghouse for Uddannelsesforskning, Aarhus Universitet. De seneste års udvikling viser, at et rekordhøjt antal unge falder fra på erhvervsuddannelserne.

Tabel 1: Frafaldsprocenter på henholdsvis de gymnasiale og de erhvervsfaglige uddannelser ${ }^{1}$

\begin{tabular}{llllllll}
\hline & 2006 & 2007 & 2008 & 2009 & 2010 & 2011 & 2012 \\
\hline Gymnasiale uddannelser & $16 \%$ & $15 \%$ & $14 \%$ & $13 \%$ & $13 \%$ & $14 \%$ & $13 \%$ \\
Erhvervsfaglige uddannelser & $44 \%$ & $44 \%$ & $43 \%$ & $44 \%$ & $46 \%$ & $46 \%$ & $48 \%$
\end{tabular}

Som det ses af ovenstående tabel er frafaldet på erhvervsuddannelserne over tre gange større end frafaldet på de gymnasiale uddannelser. Denne udvikling står i skarp kontrast til regeringens målsætning om, at 95 procent af danskerne skal have en uddannelse. En målsætning, der har været til stede blandt skiftende regeringer gennem de sidste 15-20 år. Dertil har det også vist sig, at det primært er de fagligt svageste elever, der søger ind på erhvervsuddannelserne, hvilket i sig selv udgør et problem (DEA, 2013)

På de gymnasiale uddannelser gennemfører ca. 80 procent inden for den normerede studietid. Dette er ikke tilfældet på erhvervsuddannelserne, hvor 35 procent mænd og 24 procent kvinder gennemfører en erhvervsuddannelse inden for den normerede studietid. I 2011 var der ifølge Danmarks Statistik fem procent mænd og ni procent kvinder i gang med en erhvervsuddannelse tre år

\footnotetext{
${ }^{1}$ http://www.uvm.dk/ /UVM-DK/Content/News/Udd/Erhvervs/2013/Sep/130904-Frafaldet-paaerhvervsskolerne-er-stigende
} 
ud over den normerede studietid. En af årsagerne til dette kan findes i ventetid på praktikplads og hyppigere studieskift grundet manglende praktikpladser.

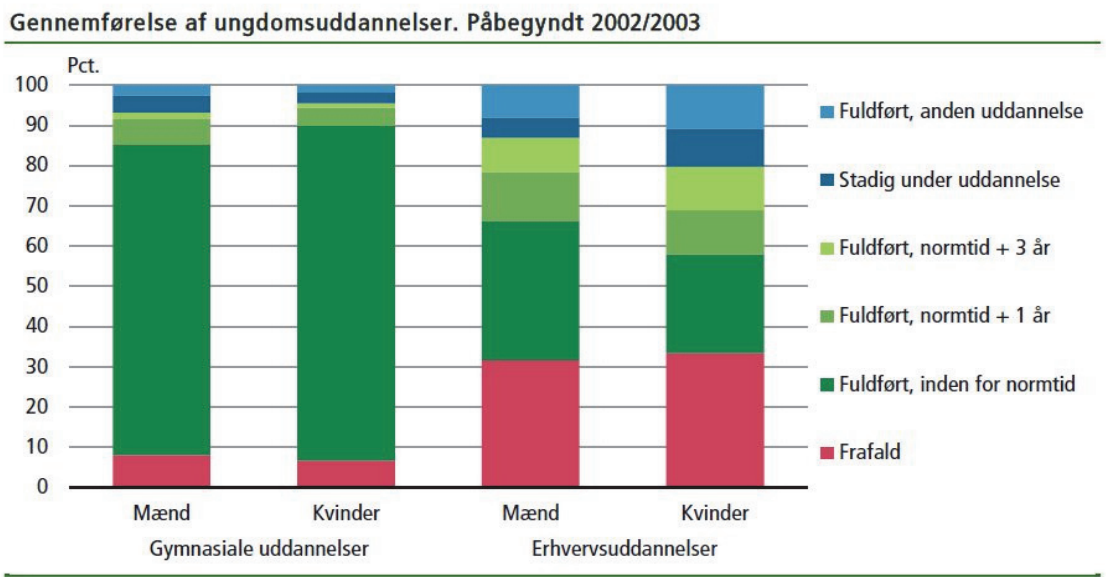

Et højt uddannelsesniveau gavner vækst og velstand i et samfund generelt, og erhvervsuddannelserne er endvidere en særdeles rentabel velfærdsøkonomisk forretning, da de tjener sig ind igen på kortere tid end de fleste andre uddannelser (Pihl, 2012). Dertil kommer, at alternativet til frafald på erhvervsuddannelserne er ufaglært arbejde og dermed minimal livstidsindkomst.

Optagelse, fastholdelse og styrket faglighed på erhvervsuddannelserne er således i den senere tid blevet et emne, der optager et væld af interessenter på området fra politikere, over professionshøjskoler til tænketanke og interesseorganisationer. Ønsket om at nedsætte frafaldet og øge optaget på erhvervsuddannelserne fordrer, at der skabes et systematisk overblik over, hvilke gavnlige og befordrende tiltag man fra politisk side kan iværksætte med henblik på at vende den negative udvikling.

Der vil derfor blive udarbejdet en brief systematisk forskningskortlægning, der har til formål at kortlægge den empirisk funderede viden fra erhvervsuddannelserne i seks europæiske lande: Danmark, Tyskland, Holland, Schweiz, England og Østrig. Feltet belyses med forskning publiceret 2005 ff. Undersøgelsen vil blive delt op i to temaer, hvor det vil blive kortlagt hvilke strukturelle, organisatoriske og institutionelle forhold, der påvirker: 1) hvorfor unge vælger at søge ind på en erhvervsuddannelse, og 2) hvorvidt unge under 


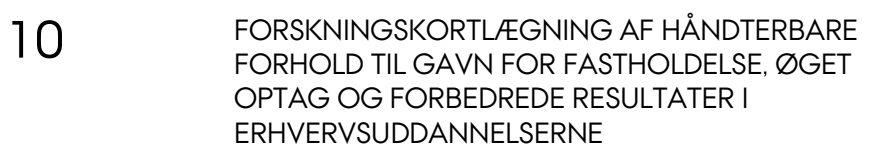

uddannelse fastholdes og gennemfører en erhvervsuddannelse, samt med hvilke resultater uddannelsen gennemføres. I fremstillingen vil blive lagt vægt på resultater fra undersøgelser, der belyser håndterbare forhold ("malleable factors"), dvs. sådanne, hvor der fra politisk hold ved en målrettet indsats kan gøres en forskel.

De to temaer vil blive undersøgt gennem forskning vedrørende hele uddannelsessystemet. Undersøgelsen vil således blive gennemført med fokus på systemet som helhed frem for med fokus på de enkelte uddannelsesretninger eller den enkelte uddannelsesinstitution. Hermed vil undersøgelsen omfatte faktorer, der direkte kan påvirkes fra politisk side.

De to temaer er:

1. Indgang til erhvervsuddannelser: Under dette tema kortlægges, hvilken overordnet policy, forskningen peger på, kan have en gavnlig effekt på uddannelsesvalg, motivation og succesfuld rekruttering. Herunder kunne man eksempelvis forestille sig at belyse adgangsbegrænsninger/forudsætninger, udformning og udbredelse af studieretninger, og muligheder for videreuddannelse, samt offentlig prestige, ranking og branding. Sammenfattet har dette tema til formål at undersøge, hvad der får unge til at søge ind på en erhvervsuddannelse.

2. Under uddannelse: Det andet tema har til formål at kortlægge hvilken overordnet policy, der synes at reducere elevernes frafald samt højne deres gennemførelsesrate og resultater, mens de er indskrevet på en erhvervsuddannelse. Organisering af uddannelsesinstitutionerne, fagretningerne, studievejledning, praktikmodeller, finansiering og tilskud samt timefordeling kunne indgå herunder. Sammenfattet er temaets formål at kortlægge, hvilke strukturelle betingelser der får flest unge til at gennemføre en erhvervsuddannelse og til at præstere optimalt.

\section{Reviewspørgsmål}

De to temaer vil blive undersøgt gennem følgende reviewspørgsmål: Hvilke politisk håndterbare forhold kan via en målrettet indsats gøre en forskel i forhold til elevoptag, elevfrafald og elevudbytte på erhvervsuddannelserne? 


\section{Reviewer}

Da dette er en brief forskningskortlægning har der ikke været tilknyttet en egentlig reviewgruppe. I stedet har lektor Vibe Aarkrog fungeret som reviewer på processen. Vibe Aarkrog har bidraget med input til processen undervejs $\mathrm{i}$ relation til søgninger og studier.

\section{Rapportens opbygning}

Kapitel 2 beskriver det metodiske grundlag. Her omtales de begrebsmæssige rammer for arbejdet og de databaser og profiler, som er anvendt til at finde relevante undersøgelser. Dernæst behandles screeningen af de mange fund fra søgningerne. Endelig behandles de fremgangsmåder, der er taget i anvendelse til at uddrage data i de relevante undersøgelser.

I kapitel 3 tematiseres og gennemgås de 27 inkluderede studier. Kapitel 4 er en sammenfatning af de overordnede resultater. I kapitel 5 gives en kort karakteristik over den inkluderede forskning. 


\section{Metoder anvendt i forskningskort- lœgningen}

\section{Brief systematisk forskningskortlœgning}

I en forskningskortlægning foretages en systematisk beskrivelse og afdækning af forskningen som defineret af et reviewspørgsmål (Gough et al., 2012). En forskningskortlægning adskiller sig fra et review ved, at resultaterne af forskningen ikke syntetiseres, men Clearinghouse's forskningskortlægninger indeholder også sammenfatninger af den kortlagte forskning, hvor de overordnede tendenser af forskningen beskrives.

En brief systematisk forskningskortlægning gennemføres hurtigere end en traditionel, fuld systematisk forskningskortlægning og adskiller sig ved, at den kan skabe overblik over et felt inden for en kortere tidsperiode end traditionel, systematisk kortlægning, der normalt varer ca. 1/2 år. En systematisk forskningskortlægning og en brief forskningskortlægning bygger på fælles principper og gennemløber ens processer, men i en brief forskningskortlægning arbejdes mindre i dybden i de forskellige faser af processen. Disse belyses nærmere i det følgende.

\section{Begrebsmcessige afgrcensninger}

I denne forskningskortlægning er der ledt efter svar på reviewspørgsmålet:

Hvilke politisk håndterbare forhold kan, via en målrettet indsats, gøre en forskel i forhold til elevoptag, elevfrafald og elevudbytte på erhvervsuddannelserne?

Ved gennemførelsen af forskningskortlægningen blev følgende begrebsmæssige bestemmelser og afgrænsninger anvendt: 


\section{Erhverosuddannelser}

Erhvervsuddannelser er erhvervsrettede ungdomsuddannelser, der forbereder eleven til et bestemt erhverv. Erhvervsuddannelser kan påbegyndes direkte efter grundskolens afslutning. Erhvervsuddannelser er af overvejende teknisk/praktisk art, og eleven er kvalificeret til at begynde i arbejde/job straks efter endt uddannelse. Der er tale om uddannelser inden for følgende områder: Bygge og anlæg, håndværk og teknik, fra jord til bord, mekanik, transport og logistik, det merkantile område, service og teknologi og kommunikation.

Politisk håndterbare forhold

Alle tiltag, der kan påvirkes gennem uddannelsespolitik. Der er tale om overordnede tiltag, der påvirker hele erhvervsuddannelsessystemet og ikke kun lokalt på den enkelte institution eller uddannelse.

\section{Elevoptag}

Elevoptag forstås som elever, der starter på en erhvervsuddannelse. Det undersøges både gennem undersøgelsen af indsatser for at øge optaget og gennem undersøgelser af elevernes interesser og motivation, som kan påvirke optaget.

\section{Elevfrafald}

Der er tale om frafald, når en elev stopper på en påbegyndt erhvervsuddannelse, inden den er fuldført.

\section{Elevresultater}

Elevresultater forstås som elevernes almenfaglige samt erhvervsfaglige udbytte.

\section{Tidsmæssig afgrænsning}

Forskningskortlægningen er tidsmæssigt afgrænset til studier, der er publiceret i 2005 eller senere.

\section{Geografisk afgrænsning}

Geografisk er forskningskortlægningen afgrænset således, at der er inddraget studier fra Danmark, Sverige, Tyskland, Holland, Schweiz og Østrig. 
Opsummerende undersøges i kortlægningen de tre forhold elevoptag, elevfrafald og elevresultater, samt hvordan disse kan påvirkes gennem politisk håndterbare forhold som illustreret i nedenstående figur:

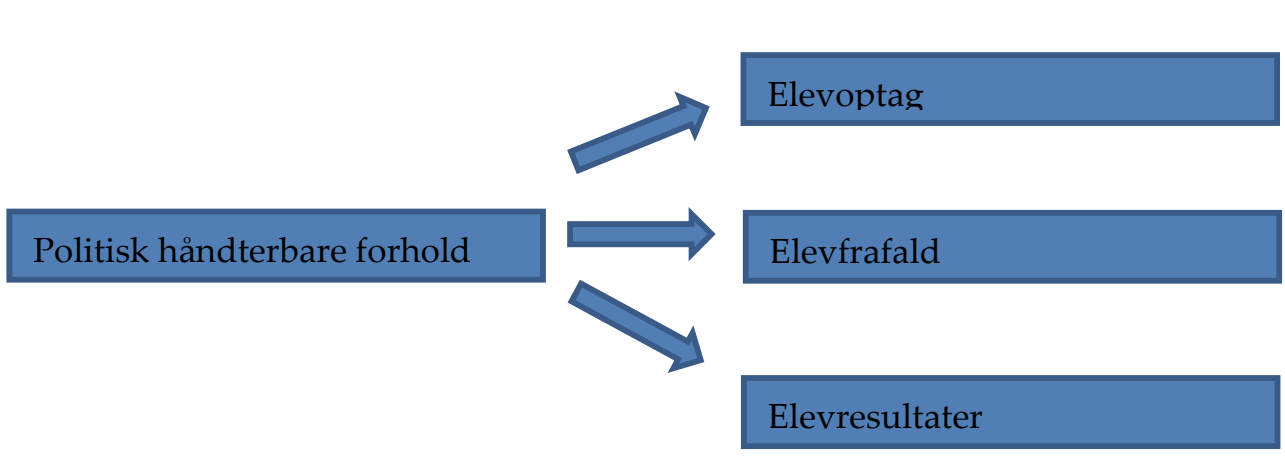

\section{Søgning}

Tabel 2 herunder viser hvilke databaser, der er afsøgt, hvornår de er afsøgt og antallet af hits.

\begin{tabular}{llc|}
\hline Ressource & Søgedato & Hits \\
\hline ERIC (Proquest) & 27.09 .2013 & 556 \\
\hline Fis Bildung & 27.09 .2013 & 281 \\
\hline Forskningsdatabasen & 30.09 .2013 & 155 \\
\hline Bibliotek.dk & 07.10 .2013 & 757 \\
\hline DiVA & 16.10 .2013 & 319 \\
\hline CEDEFOP & 16.10 .2013 & 463 \\
\hline Libris & 16.10 .2013 & 15 \\
\hline Datenbank SKBF & 18.10 .2013 & 47 \\
\hline Handsearch journals & 18.10 .2013 & 475 \\
\hline Handsearch & 20.12 .2013 & 9 \\
\hline References from references & Continuous & 9 \\
\hline References from reviewer & Continuous & 0 \\
\hline
\end{tabular}

Tabel 2: Foretagne søgninger og hits 
Der er fundet 3.086 referencer.

Baser og ressourcerne i tabellen er disse:

- ERIC er den største pædagogiske database i verden. Den er afsøgt i versionen hos databaseudbyderen, Proquest. ERIC er mest dækkende for den angloamerikanske forskning, men dækker også anden uddannelsesforskning.

- FIS Bildung er den største database for tysksproget pædagogisk litteratur. Den indeholder udover litteratur fra Tyskland, også litteratur fra Østrig, Schweiz og andre lande med udgivelser på tysk.

- Forskningsdatabasen er database for danske forskningsinstitutioner.

- Bibliotek.dk er en database for udgivelser på de danske biblioteker.

- DIVA er en svensk database for svenske forskningsinstitutioner.

- Libris er en de svenske universiteter og forskningsbibliotekers database.

- Datenbank der SKBF er en database over schweizisk uddannelsesforskning

- CEDEFOP er en database, der dækker udgivelser fra Det europæiske center for erhvervsuddannelser.

- Der er foretaget en håndsøgning i tre centrale internationale tidsskrifter om erhvervsuddannelserne. Disse er Journal of Vocational Education and Training, Vocations and Learning og European Journal of Vocational Training.

- Udover de ovennævnte databaser er udgivelser fra tre store forskningsinstitutioner, Danmarks Evalueringsinstitut, KORA og SFI, blevet håndsøgt efter relevante undersøgelser.

- Er der i studierne fundet henvisninger til øvrige relevante studier, er disse blevet kategoriseret som referencer fra referencer.

- Til at supplere de fundne referencer er projektets reviewer blevet spurgt om studier ud over de fundne (referencer fra reviewer).

I sproglig henseende er der søgt efter forskning på dansk, svensk, engelsk og tysk. Der er søgt efter studier om erhvervsuddannelserne, der vedrører elevoptag, elevfrafald og elevresultater. Sigtet med søgningerne har været at finde al forskning om erhvervsuddannelserne og de tre politisk håndterbare forhold. Der er derfor fundet et stort materiale. I screeningen, se nedenfor, har der der- 


\section{FORSKNINGSKORTL/EGNING AF HÅNDTERBARE FORHOLD TIL GAVN FOR FASTHOLDELSE, ØGET OPTAG OG FORBEDREDE RESULTATER I \\ ERHVERVSUDDANNELSERNE}

for været meget materiale, der skulle sorteres fra på grund af manglende relevans.

\section{Screening}

En del af databaserne, der er afsøgt, har overlap. Derfor har det været nødvendigt at fjerne dubletter. En given reference skal naturligvis kun optræde en gang. Der er fjernet 65 dubletter. For at finde studier, der var relevante i forhold til at undersøge reviewspørgsmålet, blev de resterende 3.021 studier screenet efter følgende inklusionskriterier:

\section{Eksklusion}

- Ikke fra Danmark, Sverige, Holland, Tyskland, Schweiz eller Østrig. Wrong Country

- Ikke en empirisk undersøgelse: Wrong paper

- Studierne undersøger effekten af indsatser rettet mod didaktisk-metodiske forhold: Wrong scope

- Studiet undersøger ikke forhold relateret til optagelsesvalg, frafald/fastholdelse eller resultater: Wrong scope

- Studiet undersøger kun socioøkonomiske baggrunde i forhold til optagelsesvalg, frafald/fastholdelse eller resultater: Wrong scope

- Undersøgelser af sammenhænge mellem indsatser rettet mod elever i erhvervsuddannelserne og outcomes senere i livsforløbet fx på arbejdsmarkedet eller socioøkonomiske forhold. Wrong scope

- Studierne omhandler en speciel gruppe af børn med diagnoser og særlige behov: Wrong scope.

\section{Inklusion}

- Studierne undersøger hvilke politisk håndterbare forhold, der har betydning for optagelsesvalg, elevresultater og elevfastholdelse i erhvervsuddannelserne. 
Kvaliteten af forskningen indgik ikke i screeningen. Dette forhold spiller først en rolle, efter screeningen, hvor alle relevante undersøgelser var identificeret. I første omgang er der sorteret på baggrund af oplysninger, der findes om referencerne i de afsøgte databaser, dvs. særligt titler og abstracts. Eksklusion er kun sket på et sikkert grundlag. Medarbejdere fra Clearinghouse har gennemført screeningen, og ved studier, hvor der har været tvivlsspørgsmål, har to medarbejdere screenet pågældende studier. Undervejs i processen har mange referencer været midlertidigt placeret under "Utilstrækkelig information til sikker screening". Først når det dokument, referencen henviste til, blev fremskaffet, har referencen kunnet fjernes fra denne placering. Det samlede resultat af screeningens to processer er skitseret i Tabel 3 herunder. 


\begin{tabular}{|c|c|c|}
\hline $\begin{array}{l}\text { Grund til eksklusion/ } \\
\text { inklusion }\end{array}$ & Grund forklaret & Antal \\
\hline Forkert scope & $\begin{array}{l}\text { Reference bidrager ikke med viden om hvilke poli- } \\
\text { tisk håndterbare forhold, der kan have en virkning } \\
\text { på valg af, frafald på eller resultater på erhvervsud- } \\
\text { dannelserne. }\end{array}$ & 2512 \\
\hline Forkert dokument & $\begin{array}{l}\text { Referencen redeg } \varnothing \text { r ikke for empirisk forskning. Fx } \\
\text { policy-dokumenter, anmeldelser, "opinion papers", } \\
\text { manualer, lærebøger, bibliografier, teoretiske papi- } \\
\text { rer, filosofiske analyser, rent forskningsmetodologi- } \\
\text { ske bidrag. }\end{array}$ & 70 \\
\hline Forkert forskning & $\begin{array}{l}\text { Referencen bidrager ikke med data og resultater fra } \\
\text { original forskning, fx forholder sig kun til forskning } \\
\text { udført og rapporteret af andre. Systematiske re- } \\
\text { views inkluderes dog. }\end{array}$ & 45 \\
\hline Forkert sprog & $\begin{array}{l}\text { Referencen er ikke publiceret på dansk, engelsk, } \\
\text { svensk eller tysk }\end{array}$ & 8 \\
\hline Forkert skolekontekst & $\begin{array}{l}\text { Referencen bidrager ikke med data eller resultater } \\
\text { om erhvervsuddannelserne }\end{array}$ & 21 \\
\hline Forkert land & $\begin{array}{l}\text { Referencen giver ikke data og resultater fra Dan- } \\
\text { mark, Holland, Schweiz, Sverige, Tyskland eller } \varnothing \text { st- } \\
\text { rig. }\end{array}$ & 321 \\
\hline Forkert tidspunkt & Referencen er publiceret før 2005 & 2 \\
\hline $\begin{array}{l}\text { Markering utilstrækkelige } \\
\text { oplysninger }\end{array}$ & Utilstrækkelig information til sikker screening & 1 \\
\hline Inklusion & $\begin{array}{l}\text { Original empirisk forskning om politisk håndterbare } \\
\text { forhold, der kan have en virkning på valg af, frafald } \\
\text { på eller resultater på erhvervsuddannelserne. }\end{array}$ & 41 \\
\hline
\end{tabular}

Tabel 3: Oversigt over den samlede screening

\section{Referencescreening og fuldtekstscreening}

Ét studie kunne ikke fremskaffes gennem kontakt til biblioteker, forfatter eller forfatterens institut. 41 referencer, som rapporterer om 36 forskellige unders $\varnothing$ gelser, blev inkluderet. Disse 36 undersøgelser er alle blevet genbeskrevet og kvalitetsvurderet af medarbejdere fra Clearinghouse. 
I første omgang er der sorteret på baggrund af oplysninger, der findes om referencerne i de afsøgte databaser, dvs. titler, abstracts osv. Selve sorteringen, eksklusion eller inklusion, er sket systematisk.

Eksklusion er kun sket på sikkert grundlag. Undervejs i processen har mange referencer været midlertidigt placeret under: 'Markering utilstrækkelige oplysninger'. Først når der var skaffet yderligere informationer om referencen, eller når det dokument, som referencen viser hen til, blev fremskaffet, har referencen kunnet fjernes fra denne placering.

Alt, der ikke sikkert kunne ekskluderes i referencescreeningen, dvs. foreløbigt inkluderet, er derefter fremskaffet. Alle de fremskaffede bøger, rapporter og artikler er derefter screenet på baggrund af den fulde tekst.

\section{Genbeskrivelse/datauddragning af undersøgelser}

De 36 undersøgelser er alle blevet genbeskrevet og kvalitetsvurderet af medarbejdere fra Clearinghouse.

Et særligt genbeskrivelses- og vurderingssystem, "EPPI Centre data extraction and coding tool for education undersøgelses v2.0", er taget i anvendelse. Systemet er skabt af EPPI-Centre ved Institute of Education, London University, som er en af Clearinghouse's internationale samarbejdspartnere. Clearinghouse har erfaring med anvendelse af systemet igennem syv år i mange reviewprocesser. På baggrund af denne erfaring er der foretaget nogle få redaktionelle ændringer i systemet rettet mod løsning af den foreliggende opgave. EPPI-systemet muliggør genbeskrivelse og vurdering af både mere kvantitativt og mere kvalitativt orienterede undersøgelser. Det må derfor anses for velegnet til genbeskrivelse af den type undersøgelser, der indgår her.

Udover dette almene system har Clearinghouse skabt et mindre genbeskrivelsessystem rettet direkte mod beskrivelse af nærværende forskningskortlægnings scope, politisk håndterbare forhold på erhvervsuddannelser.

Alle undersøgelser er genbeskrevet og kvalitetsvurderet med både det almene og det specifikke system. Både det almene og det reviewspecifikke genbeskrivelsessystem indeholder en række spørgsmål, der skal besvares for alle undersøgelser. 


\section{FORSKNINGSKORTLÆGNING AF HÅNDTERBARE FORHOLD TIL GAVN FOR FASTHOLDELSE, ØGET OPTAG OG FORBEDREDE RESULTATER I \\ ERHVERVSUDDANNELSERNE}

Det almene system dækker en undersøgelses formål, kontekst, design, metode, resultater og forsknings- og rapporteringskvalitet. Det består af sektioner, som indeholder spørgsmål, som er forbundet med multiple choicesvarmuligheder. Der kan overalt indsættes uddybende kommentarer til givne afkrydsningssvar.

Det reviewspecifikke system er opbygget med samme struktur som det almene system. Det dækker: karakteristika ved vurdering af håndterbare forhold til gavn for fastholdelse, øget optag og forbedrede resultater i erhvervsuddannelserne. Genbeskrivelserne er foretaget $i$ et samarbejde mellem medarbejdere fra Clearinghouse. Kortlægningen af feltets forskning er baseret på genbeskrivelserne af de 36 undersøgelser. 
Figur 1 viser forskningskortlægningens forløb fra søgehits til den genbeskrevne mængde af undersøgelser med tilstrækkelig forskningskvalitet.

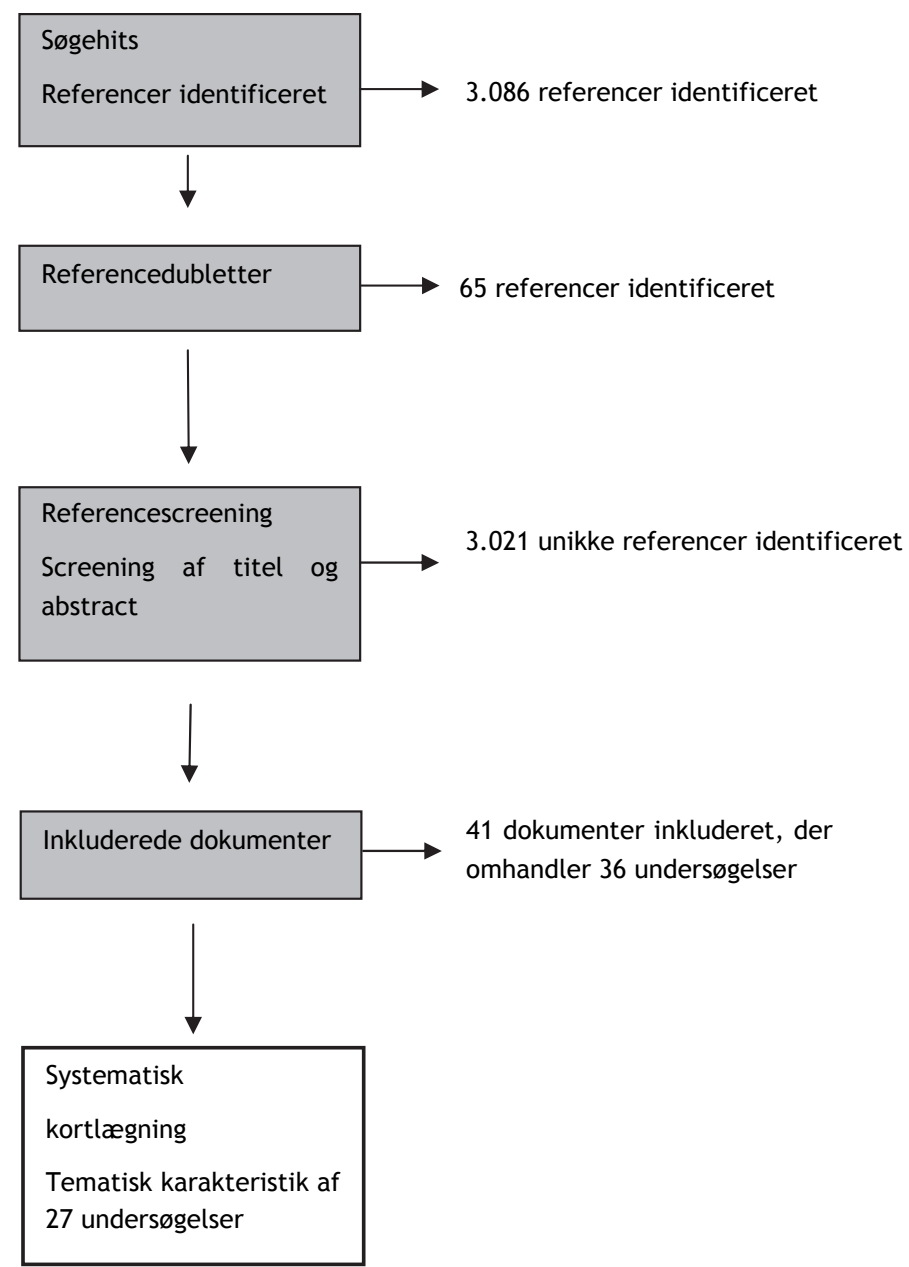

Figur 1: Filtrering af referencer fra søgning over kortlægning 


\section{Håndterbare forhold til gavn for fastholdelse, øget optag og for- bedrede resultater i erhvervsud- dannelser}

Der er 27 studier, som kan belyse spørgsmålet om, hvilke håndterbare forhold der er til gavn for fastholdelse, øget optag og forbedrede resultater for elever på erhvervsuddannelser. De 27 studier har en tilstrækkelig forskningsmæssig kvalitet på området, dvs., studiernes resultater kan give belæg for videnskabeligt baserede anvisninger til policy.

De 27 studier er inddelt i fire temaer: Motivationsfaktorer for elever på erhvervsuddannelser, Længde af og teoretisk indhold på erhvervsuddannelser, Skolepraktik og praktikpladser i virksomheder og Frafald på erhvervsuddannelser.

\section{Motivationsfaktorer for elever på erhvervsuddannelser}

De otte studier i denne kategori undersøger, hvilke motivationsfaktorer der har en betydning for, om elever vælger eller gennemfører en erhvervsuddannelse. Geografisk fordeler studierne sig således: to fra Holland og seks fra Danmark. De hollandske studier

I Jonker (2006) er formålet med studiet at undersøge, hvordan elever, som er faldet fra deres erhvervsuddannelse, oplever og forklarer deres uddannelsesmæssige nederlag.

Data består af livshistorieinterviews fra to elever, som er faldet fra en sundhedsfaglig erhvervsuddannelse. Livshistorierne stammer fra et større et- 
nografisk forskningsprojekt om motivation og forhåbninger blandt 150 elever på en erhvervsskole for sundhedspleje i Amsterdam. De to udvalgte elever forskellige på en række områder som for eksempel køn, social baggrund, etnicitet, skoleforløb og attitude. Den ene elev er en tosproget pige, hvis familie kommer fra Tyrkiet. Hendes far har, hvad forfatteren kalder et 'arbejderklassejob', mens hendes mor er hjemmegående husmor. Den anden elev og hans familie er indfødte hollændere, hvor begge forældre har, hvad forfatteren kalder et 'middelklassejob'.

På trods af de to elevers forskelligheder kan der spores en række vigtige fælles aspekter i deres erfaringer fra deres skolegang. De føler begge, at de ikke modtog anerkendelse fra deres lærere med hensyn til, hvem de var, hvad de gerne ville, og hvad de kunne opnå. Samtidig føler begge, at deres arbejdsindsats blev fejlfortolket som manglende vilje til at lære, ligesom de begge oplevede, at de blev ydmyget i klasseværelset og i praktikken, og at de blev efterladt uden støtte til at finde vej gennem uddannelsessystemet. Deres forskellige livshistorier peger således på en mangfoldighed og kompleksitet blandt elever, som falder fra en erhvervsuddannelse.

De to udvalgte livshistorier, som analysen bygger på, er særligt interessante, idet eleverne kun til dels passer ind i billedet af den stereotype, modvillige elev. De har begge et stort ønske om at lære og tilegne sig viden og bestå deres eksaminer, men ingen af dem ved hvordan. Derudover er ingen af dem præget af den sammensætning af stereotype elevrelaterede risikofaktorer, som ofte ses hos frafaldstruede elever, herunder blandt andet dårlige boglige præstationer, splittede familieforhold eller uuddannede forældre.

En nærlæsning og sammenligning af de to livshistorier viser, at begge elever har nogle stærke negative selvopfattelser, som kan være medvirkende til at mindske deres chancer for at opnå succes i skolen. Eksempler på sådanne negative, selvbekræftende selvopfattelser er, "jeg kan ikke huske noget af det, jeg har læst", "der må være noget i vejen med min hjerne", eller "jeg er ikke ligesom dem". Analysen viser, at sådanne negative selvopfattelser kan forstås som stempler, som blandt andre lærere, studievejledere og skoleinspektører sætter på elever allerede tidligt i deres skolegang. Disse stempler centreres omkring opfattelser af elevernes evne og/eller vilje til at lære og deres chancer for at op- 
nå succes i skolen. Når disse stempler er overdrevent negative, har de en tendens til at blive faste, negative selvopfattelser i elevernes sind, som på et tidspunkt vil begrænse elevernes potentialer til at tro på sig selv og tro på muligheden for at blive 'nogen' i kraft af en uddannelse. Studiet peger med andre ord på, at når eleven reproducerer sådanne stempler i form af negative, selvbekræftende selvopfattelser, øges risikoen for at falde fra sin uddannelse. På trods af gentagne forsøg lykkedes det ikke de to udvalgte elever at finde en måde, hvorpå de kunne passe ind i skolen, for på den måde at kunne klare sig og bestå deres eksaminer. De lærte således aldrig, hvordan de kunne efterleve skolens regler og forventninger til, at børn tilpasser sig med tiden og i harmoni med lærernes forventninger om passende opførsel og præstationer. De to livshistorier er eksempler på, hvordan skoler og lærere har magten til enten at stimulere og opmuntre elever til at uddanne sig eller til at tage modet fra og ekskludere elever fra uddannelsessystemet. Hermed peger studiet på vigtigheden af at se nærmere på dynamikken i interaktionen mellem elever, lærere, studievejledere og skoleinspektører frem for at bebrejde den enkelte elev og hans/hendes familie, at eleven frafalder sin uddannelse. Forskeren konkluderer herved, at det at droppe ud af en uddannelse ikke er en pludselig beslutning, men derimod en længerevarende proces.

I det andet hollandske studie af Elffers et al. (2012) undersøges, hvordan hidtidige skoleoplevelser og erfaringer indenfor en række områder påvirker erhvervsskoleelevers emotionelle tilknytning til deres skole i det hollandske uddannelsessystem. Det antages, at det mindsker sandsynligheden for frafald, hvis elever besidder en stærk tilknytning til deres uddannelsessted. Den emotionelle tilknytning deles i studiet op i tre dimensioner: 1) generel holdning til skolen og identifikation med det at være studerende, 2) en socialt betinget fornemmelse af at føle sig hjemme på skolen og blandt andre studerende, og 3) en vurdering af uddannelsens indhold og brugbarhed. For hver dimension undersøges betydningen af elevernes oplevelse af, hvorvidt deres uddannelse passer godt til dem. Derudover undersøges betydningen af, i hvor høj grad eleverne værdsætter skolens personale, hvordan de passer ind i forhold til deres klassekammerater, skolemiljøet, hvor svær de finder deres uddannelse, hvor strikte 
skolens regler er, hvor meget autonomi de har på uddannelsen samt en række baggrundsforhold.

Studiets design har karakter af en tværsnitsundersøgelse, hvor der blev indsamlet data fra 909 førsteårselever opdelt i 60 grupper, fra 40 erhvervsskoler ved brug af spørgeskemaer fra foråret 2009. Erhvervsskolerne blev udvalgt på baggrund af ønske om deltagele samt variation mellem ydre forhold som fx land- og byområder. Data blev analyseret gennem en flerniveaus regressionsmodel.

Studiets resultater peger på to hovedkonklusioner. For det første viser analysen, at elevernes opfattelse af undervisere og personale på erhvervsskolerne, ikke har nogen betydning for deres emotionelle tilknytning til skolen. Hverken i forhold til at føle en generel identifikation med skolen og rollen som studerende, $\mathrm{i}$ forhold til at have et socialt tilhørsforhold til sine medstuderende eller i forhold til indtrykket af skolen som kvalificeret uddannelsesinstitution. Der er heller ingen sammenhæng mellem, hvor strikt eleverne opfatter skolens regelsæt, og deres emotionelle tilknytning til skolen.

For det andet viser resultaterne, at elevernes opfattelse af, hvorvidt deres specifikke uddannelse var spændende og brugbar, har den største indflydelse på deres emotionelle tilknytning blandt de undersøgte forhold. Det samme kan, i lidt lavere grad, siges om elevernes selvopfattelse i forhold til, hvor godt de passer ind blandt deres klassekammerater. Disse sammenhænge er positive og øger således elevernes emotionelle tilknytning til deres skole og mindsker på sigt, ifølge forfatterne, også sandsynligheden for frafald.

Udover hovedresultaterne viser undersøgelsen, at en stigning antallet af elever, der finder studiet svært, mindsker deres generelle tilknytning til skolen, men det mindsker ikke deres følelse af at høre socialt hjemme på skolen, eller deres opfattelse af skolen som et kvalificeret uddannelsessted. Elevernes opfattelse af graden af autonomi påvirker derimod deres tilknytning til skolen, både i forhold til socialt tilhørsforhold og den generelle tilknytning og identifikation med det at være studerende, i en negativ retning.

Studiets resultater peger således samlet på, at elevernes opfattelse af, at deres uddannelse har en vis værdi, ved at de føler sig godt tilpas socialt på uddannelsesstedet, samt at de selv opfatter deres specifikke uddannelsesretning 
som værdifuld, uden at den er alt for fagligt vanskelig, og for meget er overladt til elevernes selvbestemmelse.De syv danske studier

I en undersøgelse foretaget af Danmarks Evalueringsinstitut (2013) er formålet at tilvejebringe viden dels om de forhold, der har betydning for studenternes uddannelsesvalg og -forløb, dels om de tanker og forestillinger om uddannelse, der findes blandt gruppen af studenter, som vælger at tage både en gymnasial uddannelse og en erhvervsuddannelse.

Studiet er en mixed methods-undersøgelse, hvor der er gjort brug af data vedrørende 31.071 studenter fra årgang 2007. I undersøgelsen ses bort fra dimittender fra studenterkurser, hf-enkeltfag og personer med international studentereksamen. Undersøgelsen bygger på følgende kvalitative og kvantitative datakilder:

- Registerundersøgelse baseret på data leveret af Danmarks Statistik

- Spørgeskemaundersøgelse blandt studenter fra 2007, der per oktober 2011 er i gang med eller har gennemført en erhvervsuddannelse

- 20 semistrukturerede telefoninterview med studenter, der er i gang med eller har gennemført en erhvervsuddannelse.

Andelen af studenter fra overgang 2007, der er i gang med eller har afsluttet en erhvervsuddannelse, udgør 13 procent svarende til 3.909 personer.

Resultaterne af undersøgelsen tegner et overordnet billede af, at de studenter, der fortsætter på en erhvervsuddannelse, har været glade for deres gymnasietid, har karakterer, der ligger noget under andre studenters, og giver udtryk for, at de godt kunne have tænkt sig en mere praktisk rettet undervisning. Studenterne på erhvervsuddannelserne opfatter ikke deres studentereksamen som spildt tid, men snarere som en opkvalificering af deres kompetencer, der stiller dem bedre på arbejdsmarkedet, giver dem større valgmuligheder i forhold til efteruddannelse og giver dem tid til at modnes, inden de skal vælge erhvervsretning.

En femtedel af studenterne på erhvervsuddannelserne overvejede at begynde på en erhvervsuddannelse efter grundskolen, men valgte til sidst gymnasiet. Det er et gennemgående træk, at studenterne oplevede, at valget mellem en gymnasial uddannelse eller erhvervsuddannelse efter grundskolen var me- 
get skelsættende, men samtidigt ikke et vanskeligt valg. De fleste anskuer gymnasiet som en naturlig forlængelse af grundskolen.

Et fælles karakteristika for studenterne, som vælger en erhvervsuddannelse efterfølgende, er, at de oplevede valgt af en erhvervsuddannelse efter grundskolen som et skælsættende sporskifte, hvor valget af en erhvervsuddannelse efter gymnasietiden oplevedes som et enkelt skridt på vejen. Ca. to tredjedele overvejer at tage en anden uddannelse på et senere tidspunkt.

Overordnet viser undersøgelsen, at valget af en gymnasial uddannelse af mange opleves som en naturlig fortsættelse af grundskolen, hvorfor det diskuteres, i hvilket omfang dette hænger sammen med grundskolens og især udskolingens indretning. Det konkluderes på baggrund af undersøgelsen, at det derfor er vigtigt at undersøge, om og i givet fald i hvilket omfang grundskolen i sin struktur og kultur og i sit indhold peger hen mod og forbereder til de gymnasiale uddannelser. Det konkluderes, at mulighederne for at "åbne" grundskolen overfor erhvervsuddannelserne, fx ved at udvikle de praktiske fags placering og rolle i grundskolen, burde undersøges.

Pless og Katznelson (2005) har undersøgt, hvilke faktorer der motiverer valget af en erhvervsuddannelse set i forhold til en gymnasial uddannelse, 10. klasse eller ufaglært arbejde blandt elever på grundskolens ottende og niende klassetrin. Studiet indbefatter således undersøgelser af elevernes foreløbige præferencer, deres forestillinger om og indtryk af uddannelsesvalget, uddannelsernes indhold, elevernes forestillinger om sammenhængen mellem uddannelsesvalg og senere erhvervsmuligheder samt skolens og forældrenes rolle $\mathrm{i}$ forhold til uddannelsesvalg.

Studiet anvender et overvejende casestudiebaseret design, hvori kvalitative data fra interviews med elever og vejledere fra 12 niendeklasser samt en række observationer af vejledningssamtaler, forældresamtaler, forældremøder og lignende indgår. Der er også indhentet yderligere kvalitative data fra blandt andet elevernes evalueringer af praktikforløb og stile, hvori eleverne beskriver deres forestillinger om fremtidige studievalg. Disse suppleres med deskriptiv statistik baseret på spørgeskemaer besvaret af 1.158 elever fra ottende klasse.

Studiets samlede resultater i forhold til tilvalget af erhvervsuddannelser peger på to væsentlige forhold. For det første er der forskel på de elever, der i ottende 
klasse tilkendegiver, at de overvejer at vælge tekniske erhvervsuddannelser, og dem, der hælder til mere handelsorienterede erhvervsuddannelser. Drenge fra hjem med lavere uddannelsesniveau vælger oftest de tekniske erhvervsuddannelser frem for andre, og dette sammenfalder med, at de tekniske erhvervsuddannelser har langt lavere social status end både de gymnasiale uddannelser og de handelsorienterede erhvervsuddannelser. For det andet tegner studiets resultater et billede af, at eleverne overordnet forstår uddannelsesvalget som et valg mellem helt praktiske og helt boglige uddannelser, der foregår på henholdsvis en teknisk skole eller et gymnasium. Boglige uddannelser opfattes videre som finere blandt eleverne, og som noget der er forbeholdt de kløgtigere elever. I det hele taget peger resultaterne på, at de unge opfatter valget af ungdomsuddannelse som en form for prestigehierarki med de tekniske erhvervsuddannelser langt nede ad rangstigen. Endelig peger studiets resultater på, at eleverne har en lav grad af kendskab til de uddannelser, de skal vælge imellem, samt til sammenhængen mellem uddannelsesvalg og forskellige erhverv. Meget tyder også på, at en stor andel vælger gymnasiale uddannelser for at udskyde et mere definitivt uddannelsesvalg til senere i livet, hvilket ikke i samme grad synes at være tilfældet for de elever, der hælder mod at vælge erhvervsuddannelserne.

Andersen (2005) har undersøgt sammenhænge mellem en række forhold: køn, familiemæssig baggrund, fagligt niveau i niende klasse og interesser og elevernes valg af ungdomsuddannelse, herunder erhvervsuddannelser, efter niende klasse.

Rapporten bygger på data fra PISA-undersøgelsen fra 2000, hvor elever fra årgangene 1983 og 1984 fik testet deres færdigheder, ligesom de besvarede et spørgeskema om egne forhold. I 2004 blev 3.073 af de testede elever fra årgang 1984 interviewet vedrørende valg af uddannelse, interesser, og hvad der havde betydning for valg af uddannelse efter niende klasse. I nærværende rapport anvendes kun data fra 2004, og undersøgelsen er dermed et tværsnitsstudie. I rapporten undersøges sammenhænge mellem valg af uddannelse og elevernes begrundelser for valg af uddannelse gennem kvantitative analyser. Der skelnes mellem tre erhvervsuddannelser: 1) handelsskolernes uddannelser (bortset fra hhx), 2) uddannelser på tekniske skoler og social- og sundhedsud- 
dannelser (SOSU), 3) fire gymnasiale uddannelser, det almene gymnasium, hf, htx og hhx. De tekniske skoler omfatter en række meget forskellige uddannelser såsom bygge- og anlæg, mekanik, håndværk, teknik og service. Eleverne på hver af de syv uddannelser blev præsenteret for 14 forskellige forhold, der hver især kunne have haft betydning for beslutningen om, hvad de skulle lave efter grundskolen. Vægten af forholdene udregnes for eleverne på hver af de syv uddannelser, så elever der valgte forskellige uddannelser, kan sammenlignes.

Overordnet viser rapportens resultater, at elever på erhvervsuddannelserne i højere grad end elever på de gymnasiale uddannelser samlet set angav skoletræthed, behov for at tjene penge og positive erfaringer fra erhvervspraktik som begrundelser for valg af uddannelse. En fjerde væsentlig begrundelse for valg af erhvervsuddannelse var fremtidige beskæftigelsesmuligheder, men denne begrundelse var mere væsentlig for elever fra de gymnasiale uddannelser. Faglige interesser var en af de væsentligste begrundelser for valg af uddannelse for både elever fra de gymnasiale og de erhvervsrettede uddannelser. For elever fra handelsskoler og SOSU var det dog en mindre væsentlig begrundelse sammenlignet med elever fra det almene gymnasium, htx og de tekniske skoler, hvor det for sidstnævnte var den væsentligste begrundelse.

Danmarks Evalueringsinstitut (2012) har undersøgt, hvilke typer af indsatser eleverne i 10. klasse tilbydes efter indførelsen af nye regler, og hvilke faktorer der har betydning for at øge elevernes motivation for at starte på en ungdomsuddannelse. De nye regler om 10. klasse, der er trådt i kraft fra skoleåret 2008/09, handler bl.a. om, at 10. klasse skal målrettes de elever, som efter 9 . klasse har behov for yderligere faglig opkvalificering og afklaring af uddannelsesvalg for at kunne gennemføre en ungdomsuddannelse.

Denne evaluering er anden del ud af tre dele af en større evaluering af 10. klasse.

Studiet er udformet som et longitudinelt kohortestudie, der udover at inddrage data fra første del af evalueringen, indsamler data ved hjælp af telefoninterviews med 15 lærere i 10. klasse, spørgeskemaundersøgelse blandt elever i 10. klasse ( $\mathrm{N}=2.902)$ og spørgeskemaundersøgelse blandt lærere i 10. klasse $(\mathrm{N}=558)$. Analysestrategierne består af (1) en deskriptiv analyse, (2) sammenholdelse af elevspørgeskemabesvarelser fra 9. klasse og 10.klasse og (3) ved 
hjælp af en statistisk model en undersøgelse af, hvilke faktorer der har betydning for, om eleverne øger deres motivation for en ungdomsuddannelse.

Resultaterne viser, at der er stor variation i, hvilke indsatser der tilbydes i 10 . klasserne. Indsatserne er særligt afhængige af, hvilken skoleform der udbyder 10.klasse (10. klasse på folkeskole, 10.-klasse-center, ungdomsskole, privatskole/friskole eller efterskole). 10. klassetilbuddene på folkeskolerne og i 10.-klassecentrene vægter brobygning højt og tilbyder længerevarende brobygningsforløb. I løbet af brobygningsforløbet etableres desuden et længerevarende samarbejde med ungdomsuddannelserne rettet mod at udvikle brobygningsforløbene. Ligeledes prioriterer ungdomsskolerne de afklarende indsatser, $\mathrm{fx}$ ved at der ligeledes er hyppigere obligatoriske brobygningsforløb. På efterskolerne er vejledning i højere grad tilgængelig sammenlignet med andre skoleformer ved, at vejledere også er lærere på efterskolen og derfor er lettere tilgængelige for eleverne, når de har behov for vejledning.

Når elevernes vurderinger af deres egen uddannelsesparathed, skoletrivsel og motivation i 10. klasse sammenholdes med deres vurderinger i 9. klasse, ses, at den gruppe, der havde de laveste vurderinger i 9. klasse, giver mere positive vurderinger i 10. klasse. De ændrer især deres vurderinger af, hvor vigtigt det er for dem at få en ungdomsuddannelse, hvor godt de synes om at gå i skole, deres relationer til klassekammerater og lærere og deres egne personlige og sociale kompetencer. Den samlede elevgruppe udvikler sig dog ikke i samme grad.

Studiet viser desuden, at der er stor forskel på elever, der starter på en erhvervsuddannelse efter henholdsvis 9. klasse og 10. klasse. De elever, der starter på en erhvervsuddannelse efter 10. klasse, vurderer deres egen uddannelsesparathed, skoletrivsel og motivation mere positivt på de fleste parametre end de elever, der er startet på en erhvervsuddannelse umiddelbart efter 9 . klasse. Særligt er der forskel på elevernes vurderinger af deres faglige kompetencer og trivsel i skolen.

Det fremhæves i evalueringen, at det har positiv betydning for elevernes udvikling af motivation for ungdomsuddannelse i løbet af 10. klasse, at de har været tilfredse med valget af valgfag og linjer i 10. klasse, og at den vejledning, 
de har fået, har levet op til deres behov; især fremhæves vejledning om praktik og brobygning som særligt motivationsfremmende.

I Grønborgs (2011) studie undersøges, hvordan elever på mekanikeruddannelsen reagerede på et fastholdelsestiltag bestående af obligatorisk boksetræning to gange ugentligt og udarbejdelse af sundhedsprofiler, hvor eleverne fik målt kondital, vægt, BMI, kolesterol, blodtryk, fedtprocent og muskelmasse. Erhvervsskolen, hvor undersøgelsen blev gennemført, havde sundhed og idræt som et af de centrale tiltag i deres handlingsplan for øget gennemførelse. Hensigten med tiltaget er at skabe sundere elever med mere selvtillid, disciplinering og respekt for lærerne samt et bedre sammenhold i klassen for herigennem at øge sandsynligheden for, at eleverne gennemfører uddannelsen.

Studiet er et etnografisk feltstudie, hvor forfatteren var elev på et mekanikergrundforløb i 30 uger, og det empiriske materiale udgøres af feltnoter, interviewudskrifter og materiale om idrætsindsatsen. Der gik 28 elever, alle mænd, på uddannelsen, og forfatteren følger forløbet på lige fod med de andre elever. Forfatteren skriver, at der blandt eleverne både var modstand mod og tilfredshed med tiltaget, og på baggrund heraf konkluderes, at det er forsimplet at fremstille idræt og sundhed som løsning på komplekse frafaldsproblemer. I artiklen fremanalyseres særligt elevernes modstand mod tiltaget. Højst to tredjedele af eleverne mødte op til idrætstimerne, og idrætslæreren holdt op med at føre fravær for nogle elever, da for meget fravær i sidste ende kunne risikere at føre til udsmidning, hvis reglerne blev fulgt bogstaveligt. Samtidig blev det sociale sammenhold blandt eleverne på forløbet undermineret p.g.a. de mange fraværende elever, selvom det illustreres, hvordan der blev udviklet et fællesskab på trods mellem de elever, der valgte ikke at møde til idrætstimerne.

Modstanden forklares blandt andet med en manglende sammenhæng mellem idræt og sundhed på den ene side og elevernes forestillinger om, hvad det vil sige at være en mekaniker som modpol på den anden. Ifølge forfatteren opfattede eleverne idræts- og sundhedsaktiviteterne som en trussel mod deres identiteter som voksne og mekanikere, og eleverne ønskede i stedet, at tiden på uddannelsesstedet skulle bruges på arbejdsrelaterede aktiviteter. Forfatteren ser en tendens til, at det hovedsageligt var de ældste elever, der ikke ønskede at deltage i idrætstimerne. Samtidig involveredes eleverne ikke i udviklingen af 
tiltaget, hvilket antageligt mindskede deres motivation for at deltage i idrætstimerne.

Forfatteren konkluderer, at boksetræning og udarbejdelse af sundhedsprofiler ikke nødvendigvis er velegnede til at skabe sammenhold og styrke de sociale relationer. Idræt rummer potentialer til at skabe øget gennemførelse gennem kammeratskab, trivsel og motivation, men tiltagene skal tilrettelægges på en måde, hvor der er variation, samarbejde og elevindflydelse.

I et andet studie af Grønborg (2013) undersøges forholdet mellem på den ene side engagement og manglende engagement og gennemførelse og frafald på den anden side hos en gruppe elever på et mekanikerforløb. Manglende engagement, forstået som mangel på interesse for eller forpligtigelser over for det skolemæssige, anskues ikke som enten udelukkende institutionelt eller individuelt betingede, men som varierende i forskellige kontekster, hvor særligt sociale relationer spiller en stor rolle. Det undersøges særligt, hvordan elevernes engagement og manglende engagement $\mathrm{i}$ forskellige kontekster relaterer sig til muligheden for at blive en del af mekanikerkulturen og få en praktikplads.

Empirien er indsamlet på samme mekanikerforløb som i det ovenfor beskrevne etnografiske feltstudie af Grønborg (2011).

Undersøgelsen viser, at kulturen blandt eleverne på mekanikerforløbet var præget af en antiautoritær holdning og rå humor, hvor det var en del af kulturen at komme for sent til timerne, gå fra timerne og ikke at lave noget. Nogle af lærerne, der selv var tidligere automekanikere, legitimerede denne form for manglende engagement og kulturen blandt eleverne som noget, de selv kunne finde på, og som noget, der var en del af det at være mand og mekaniker. Elevernes manglende engagement $\mathrm{i}$ forhold til skolearbejdet var således en måde at blive en del af kulturen på på mekanikerforløbet. Videre viser undersøgelsen, at denne måde at agere på også var den rigtige måde at agere på i forhold til at få og holde på en praktikplads, hvor kemi og humor spillede en større rolle end elevernes kompetencer.

Hermed viser undersøgelsen overordnet, at der ikke er et lineært forhold mellem henholdsvis engagement og gennemførelse og mellem manglende engagement og frafald. Elevernes manglende engagement i forhold til skolearbejdet er samtidig et engagement i forhold til elevkulturen, men for at gennemføre 
mekanikeruddannelsen er begge former for engagement nødvendige, ifølge forfatteren. De elever, der både gennemførte kurserne på skolen og fik en praktikplads, formåede at navigere både i forhold til skolearbejdet, elevgruppen og praktikstedet. Forfatteren konkluderer hermed, at manglende engagement ikke behøver at føre til frafald, og at succes på mekanikeruddannelsen ikke blot handler om curriculum, karakterer og kompetencer.

Yderligere beskriver forfatteren manglende engagement som en måde, hvorpå eleverne kan sikre deres selvopretholdelse i et forløb, hvor det er sandsynligt, at de vil møde afvisninger og nederlag.

\section{Sammenfatning vedrørende studier rettet mod motivationsfaktorer for elever på erhvervsuddannelser}

I studierne rettet mod motivationsfaktorer for elever på erhvervsuddannelser peger resultaterne tilsammen på:

- Læreres, studievejleders og skoleinspektørers opfattelser af elevernes evne/vilje til at lære og opnå succes i skolen kan, hvis de er negative, blive varige negative selvopfattelser i elevernes sind

- Erhvervsskoler og lærere har muligheden for at stimulere og opmuntre eleven til fortsat uddannelse eller til at tage modet fra og ekskludere elever fra uddannelsessystemet

- Dynamikken i interaktionen mellem elever, lærere, studievejledere og skoleinspektører er essentiel i forhold til at fastholde elever i deres uddannelse

- Elever skal opleve deres uddannelsesretning som værdifuld, dog uden at være fagligt for udfordrende og uden for meget selvbestemmelse

- Valget af en erhvervsuddannelse efter grundskolen kan opleves som skelsættende, hvor gymnasiet anskues som en naturlig forlængelse af grundskolen

- Dimittender fra gymnasiet oplever sig som bedre rustet til at vælge og gennemføre en erhvervsuddannelse 
- I valg af ungdomsuddannelse findes et prestigehierarki, hvor de tekniske erhvervsuddannelser opleves mindre fine end erhvervsuddannelser inden for handel og især mindre fine end de gymnasiale uddannelser

- Der er et manglende kendskab til erhvervsuddannelserne og til sammenhængen mellem uddannelsesvalg og senere erhvervsmuligheder

- Valg af erhvervsuddannelse hænger ofte sammen med skoletræthed, behov for at tjene penge og positive erfaringer fra erhvervspraktik

- Faglige interesser er en væsentlig begrundelse for valg af uddannelse især i forhold til elever fra det almene gymnasium, htx og de tekniske skoler

- Elever, der starter på en erhvervsuddannelse efter 10. klasse, vurderer deres egen uddannelsesparathed, skoletrivsel og motivation mere positivt end elever, der starter efter 9. klasse

- Vejledning om praktik og brobygning er særligt motivationsfremmende for valg af ungdomsuddannelse

- Fastholdelsestiltag bestående af obligatoriske aktiviteter for elever, der ikke nødvendigvis er direkte relateret til selve erhvervsuddannelsen, er en forsimplet måde at løse komplekse frafaldsproblemer på

- Elever skal kunne navigere både i forhold til skolearbejde, elevgruppen på skolen og praktikpladsen - et manglende engagement i forhold til skolearbejde kan være et engagement i en elevgruppekultur, der er generelt negativ over for skole - men begge dele er væsentlige i forhold til gennemførelse af en uddannelse.

\section{Lœngde af og teoretisk indhold på erhvervsuddannelser}

Der er fire studier i denne kategori. Studierne undersøger, hvilken indflydelse længden af og teorimængden på en erhvervsuddannelse har på ressourcesvage elevers gennemførelse af en erhvervsuddannelse.

Geografisk fordeler studierne sig således: to fra Tyskland, et fra Schweiz og et fra Sverige.

De to tyske studier

I Uhly et al.s (2011) studie ses på, om den 2-årige erhvervsuddannelse i Tyskland er med til at forbedre ressourcesvage elevers uddannelseschancer. Den 
overvejende forskel mellem den 2-årige erhvervsuddannelse og den traditionelle 3-31/2 årige erhvervsuddannelse er, at den 2-årige erhvervsuddannelse er teorireduceret og specifikt målrettet ressourcesvage unge.

Studiet har til formål at analysere en række foreliggende statistiske data. Gennem disse statistiske analyser ønsker studiet at: 1) undersøge sammenhængen mellem en række forskellige aspekter knyttet til eleven, der kan påvirke hans/hendes uddannelsesforløb, for eksempel elevens sociale baggrund og elevens tidligere og videre uddannelsesforløb, og 2) undersøge, hvorvidt de unge efter den 2-årige erhvervsuddannelse læser videre og tager en fuld 31/2-årig erhvervsuddannelse inden for den branche/det erhverv, de har taget deres 2-årige erhvervsuddannelse.

Data udgøres af erhvervsuddannelsesstatistik (Berufsbildungsstatistik), som er statistik over unges valg af erhvervsuddannelse indsamlet på både delstatsog landsplan i Tyskland og data fra de årligt indgåede erhvervsuddannelseskontrakter fra årene 2009 og 2010.

En gennemgang af elevernes socioøkonomiske baggrund og tidligere skolepræstationer viser, at der på de 2-årige erhvervsrettede uddannelser primært er elever med lavere karakterer efter endt skolegang på grundskolen. Det vil med andre ord sige, at den ønskede målgruppe for den teorireducerede 2-årige erhvervsuddannelse vælger uddannelsen. Studiet viser desuden, at det ikke udelukkende er ressourcesvage unge, der vælger den 2-årige erhvervsuddannelse. Inden for nogle brancher er der elever, der som minimum har taget folkeskolens udvidede afgangsprøve, og inden for visse erhverv/professioner er der desuden en relativt stor andel af elever, der har gennemført gymnasiet og dermed er egnet til at studere videre på en videregående uddannelse. Der er med andre ord stor variation fra branche til branche. Eleverne på de 2-årige uddannelser er ældre end eleverne på de traditionelle 3- og 31/2-årige erhvervsuddannelser. Dette skal ses i lyset af, at flere af disse unge inden påbegyndelsen af uddannelsen har deltaget i forskellige erhvervsforberedende kurser.

På trods af at den 2-årige erhvervsuddannelse lægger op til, at eleverne kan fortsætte på en efterfølgende 3 til 31ำ-årig erhvervsuddannelse inden for den branche/profession, de har taget deres 2-årige erhvervsuddannelse, er det 
gennemsnitligt kun maksimalt $28 \%$ af eleverne, der udnytter de tilgængelige videreuddannelsesmuligheder.

Igen viser tallene dog, at der er stor variation fra branche til branche i forhold til videreuddannelse. Inden for visse brancher som for eksempel træ og byggeri læser $50 \%$ af eleverne videre, mens det for andre brancher som for eksempel cykelmontør er under $16 \%$ af eleverne, som læser videre.

Studiet konkluderer, at der på baggrund af foreliggende statistik ikke kan drages endelige konklusioner i forhold til den 2-årige erhvervsuddannelses samlede potentiale til at forbedre de ressourcesvage unges chancer for at gennemføre en videre kompetencegivende uddannelse og opnå status som faglært. Det andet tyske studie (Becker et al., 2010) er en evaluering af et projekt gennemført på erhvervsuddannelsesinstitutioner i den tyske delstat NordrheinWestfalen rettet mod elever, der på grund af personlige og faglige forudsætninger vurderes til at skulle have støtte til at gennemføre en erhvervsuddannelse. Projektet, "Den 3. vej", består af forskellige dele. Disse er: 1) muligheder for at eleverne kan forlænge uddannelsen eller lave kortvarige afbrud i uddannelsen, 2) et formaliseret samarbejde mellem uddannelsesinstitutioner og lærepladser, 3) en mere struktureret uddannelse med certifikater, der dokumenterer gennemførte moduler, tættere forhold mellem teori og praksis og klare forbindelser mellem rammeplan og uddannelse, 4) uddannelsescoaching, hvori kompetenceudvikling af eleverne og socialpædagogisk støtte indgår, samt 5) udvikling af individuelle målsætninger og planer i samarbejde med uddannelsescoachen.

Den del af rapporten, der er relevant for nærværende kortlægning, er designet som et tværsnitsstudie, hvor data om frafald og overgang til arbejdslivet blev indsamlet for 1.809 elever efter endt uddannelse. I rapporten foretages kvantitative analyser af sammenhænge mellem de forskellige instrumenter i "Den 3. vej" indsamlet på 126 uddannelsessteder og data om elevernes frafald. Der blev også afholdt to konferencer, hvor eleverne og de forskellige institutioner involveret i projektet kunne mødes. En forudsætning for at blive optaget til projektet er, at man har gået på en erhvervsrettet uddannelse.

Undersøgelsen viser, at flere dele af projektet har positive virkninger på elevernes gennemførelse af en erhvervsuddannelse. Der blev fundet en nedgang i elevernes frafald, hvis: 1) der inden eleverne blev optaget på "Den 3. vej" 
blev indhentet information fra jobcentre og lignende institutioner om eleverne, så de elever, man vurderede havde størst sandsynlighed for at gennemføre, blev optaget til projektet, 2) der var god kontakt mellem uddannelsesinstitutionerne og praktikstederne under praktikperioden, 3) uddannelsen havde certifikater, der dokumenterede gennemførte moduler, og at praktikpladserne accepterede disse og 4) en udvidelse af samarbejdet mellem de forskellige parter og institutioner i uddannelsen. Yderligere blev fundet en sammenhæng mellem en stigning i elevernes frafald og omfanget af individuelle målsætninger.

\section{Studiet fra Schweiz}

I studiet af Kammermann et al. (2011) undersøges effekten af et schweizisk uddannelsespolitisk tiltag, der består i oprettelsen af 2-årige erhvervsuddannelsesforløb målrettet elever med en svag faglig baggrund fra grundskolen. De traditionelle erhvervsuddannelsesforløb er 3-4 år lange. Målet med tiltaget er, at man vil kunne mindske frafaldet blandt elever med svag faglig baggrund væsentligt samt øge sandsynligheden for, at de får en godkendt erhvervsuddannelse, og at de kommer i arbejde efter endt uddannelse. Udover at reducere selve varigheden af erhvervsuddannelsesforløbet erstatter det nye 2-årige forløb den tidligere praksis overfor elever med svag faglig baggrund, som bestod i en form for 1-2 årig udvidet specialundervisning med et stærkt individualiseret fokus. Dette specialforløb var, modsat det nye 2-årige, segregeret, og det førte ikke til erhvervelsen af en statsligt godkendt ungdomsuddannelse. Det gør det nye 2-årige forløb.

Studiet anvender et longitudinelt design, hvori tre grupper erhvervsskoleelever indgår. Den første gruppe gennemgik det nye 2-årige erhvervsuddannelsesforløb og har en svag faglig baggrund (28 elever), den anden gruppe gennemgik samme erhvervsuddannelsesforløb, men med en gennemsnitlig faglig baggrund (261 elever), og den tredje gruppe gennemgik et traditionelt 3-årigt erhvervsuddannelsesforløb med en gennemsnitlig faglig baggrund (118 elever). Grupperne følges over tid, og de bliver sammenlignet på tre forskellige tidspunkter. En gang under selve lærlingeforløbene, en gang halvanden år efter og afsluttende tre år efter endt uddannelse. Data blev hentet fra to store schweiziske surveyprogrammer og analyseret kvantitativt gennem en ANCOVA-model. 
Studiets resultater peger på, at der er væsentlige fordele forbundet med oprettelsen af det 2-årige erhvervsuddannelsesforløb for elever med en svag grundskolebaggrund. Specielt er det værd at bemærke, at der ikke blev fundet nogen signifikant forskel mellem de tre grupper $\mathrm{i}$ forhold at kunne håndtere arbejdsbyrden på erhvervsskole eller i praktikforløbene hos virksomhederne. Det samme gør sig gældende for tilfredsheden med erhvervsskolernes lærere, med variationen i undervisningen, og når de efterfølgende i arbejdslivet bliver spurgt, om de var tilfredse med det udbytte, de havde fået af deres uddannelse. Der er således ingen statistisk forskel på de tre grupper indenfor de nævnte kategorier, men det bør understreges, at de derudover også generelt ligger i den gode halvdel af skalaen indenfor hver kategori uanset forskelle mellem grupperne. Altså er gennemsnittet over middel.

Studiets resultater tyder dog også på, at elever i den 2-årige erhvervsuddannelse med en gennemsnitlig faglig baggrund generelt er mindre tilfredse med deres uddannelse og de muligheder, det 2-årige forløb giver dem på jobmarkedet, end elever med svag baggrund. På disse punkter har de fagligt svage elever på det 2-årige forløb tilsyneladende mere til fælles med eleverne i det traditionelle 3-årige forløb.

Samlet set peger studiets resultater på, at det schweiziske tiltag med oprettelsen af et 2-årigt erhvervsuddannelsesforløb har været en succes, der øger sandsynligheden for, at elever med en svag faglig baggrund får en godkendt erhvervsuddannelse og dermed antagelig også bedre muligheder på arbejdsmarkedet.

\section{Det svenske studie}

I studiet af Hall (2012) er formålet at evaluere effekterne af et større pilotforsøg i de erhvervsrettede uddannelser i Sverige, der fandt sted forud for en reform af det svenske uddannelsessystem i 1991. Ordningen indebar primært, at de erhvervsrettede uddannelsers curricula i nogle kommuner blev mere teoretiske, og varigheden af de erhvervsrettede uddannelser øgedes fra to til tre år. Yderligere fandt en større del af den praktiske uddannelse sted på arbejdspladser frem for på uddannelsessteder, og gennemførelsen af en treårig erhvervsrettet uddannelse gav adgang til nogle universitetsstudier. I studiet undersøges, hvilken betydning pilotforsøget havde for andelen af elever, der faldt fra den er- 
hvervsrettede uddannelse. Elever, der seks år efter optagelsen på en uddannelse ikke havde gennemført en uddannelse, blev registreret som frafaldne.

Studiet er en longitudinel undersøgelse, hvor der er gjort brug af data vedrørende 184.101 elever, der færdiggjorde grundskolen i 1986-1990, og som påbegyndte en erhvervsrettet uddannelse i umiddelbar forlængelse heraf. Gennem kvantitative analyser blev elever, der valgte treårige erhvervsrettede uddannelser, sammenlignet med elever, der valgte toårige erhvervsrettede uddannelser.

Vedrørende frafald viser undersøgelsen, at sandsynligheden for at være faldet fra er 3,8 procentpoint højere for elever, der startede på en treårig erhvervsrettet uddannelse sammenlignet med elever, der startede på en toårig erhvervsrettet uddannelse. Dette gælder i særlig grad for elever med et lavt karaktergennemsnit fra grundskolen, for hvem sandsynligheden for at være faldet fra er 8,3 procentpoint højere, hvis de starter på en treårig erhvervsrettet uddannelse frem for en toårig. Et lignende billede viser sig for elever, hvis forældre ikke har mindst en treårig uddannelse. For disse elever er sandsynligheden for at være faldet fra 5,2 procentpoint højere, hvis de starter på en treårig erhvervsrettet uddannelse frem for en toårig. Det er de elever, der var relativt svagest stillet, for hvem risikoen for at falde fra steg, hvis de valgte en treårig uddannelse frem for en toårig, og forfatteren konkluderer, at undersøgelsen indikerer, at ikke alle elever drager fordel af en ungdomsuddannelse med mere teoretisk indhold.

\section{Sammenfatning vedrørende lœngde af og teoretisk indhold på erhvervsud- dannelser}

Resultaterne af de fire studier i under dette tema peger i retning af:

- En teorireduceret erhvervsuddannelse specifikt målrettet ressourcesvage elever resulterer ikke nødvendigvis $i$, at elever efterfølgende tager en videre kompetencegivende uddannelse, således at de kan opnå status som faglært

- I forhold til videreuddannelse er der stor forskel på de forskellige erhvervsuddannelser. I Tyskland ses det $f x$, at indenfor træ og byggeri er det 
$50 \%$, der tager en efteruddannelse i modsætning til cykelmontør, hvor under $16 \%$ tager en efteruddannelse

- Det har en positiv virkning på ressourcesvage elever, at der er en god kontakt mellem uddannelsesinstitutionen og praktikpladsen i praktikperioden

- Det har en positiv virkning på ressourcesvage, at de kan dokumentere gennemførte moduler overfor praktikpladsen, og at praktikpladsen anerkender dem

- Det har en positiv virkning på ressourcesvage elever, at der er et tæt samarbejde mellem de forskellige parter og institutioner i uddannelsen

- Det kan have en negativ virkning på ressourcesvage elever, hvis omfanget af deres elevplaner bliver for uoverskuelige

- Et toårigt erhvervsuddannelsesforløb for ressourcesvage elever øger mulighederne for, at de får en godkendt erhvervsuddannelse og job. Især når tilbuddet ikke er individuelt tilrettelagt for den enkelte elev og har karakter af et specialtilbud, men i stedet består i et uddannelsesfællesskab med andre elever i et fælles uddannelsesmiljø

- Elever med et lavt karaktergennemsnit fra grundskolen har en større risiko for at falde fra en treårig erhvervsuddannelse med mere teoretisk indhold.

\section{Skolepraktik og praktikpladser i virksomheder}

Der er fem studier i denne kategori. Studierne undersøger, hvilke faktorer der kan forklare faldet $\mathrm{i}$ antallet af praktikpladser i virksomheder, og hvilke faktorer der har indflydelse på, at elever gennemfører deres praktikperioder.

Geografisk fordeler studierne sig således: Fire fra Danmark og et fra Schweiz.

De fire danske studier

I rapporten af Danmarks Evalueringsinstitut (2011) redegøres for resultaterne af evalueringen af skolepraktikken på fire erhvervsuddannelser: data- og kommunikationsuddannelsen, detailhandelsuddannelsen, mekanikeruddannelsen og træfagenes byggeuddannelse. Evalueringen belyser en række generelle 
mønstre i skolepraktikken. Evalueringen bygger på registerdata vedrørende elevernes veje til og i skolepraktikken og interview på udvalgte skoler med elever, instruktører, ledere og medlemmer af lokale uddannelsesudvalg.

I alt 14 erhvervsskoler fordelt på de fire uddannelser indgår i evalueringen. Uddannelserne er valgt ud fra antallet af elever i skolepraktik (mindst 70 elever i gang med skolepraktik i juni 2010) og således, at de repræsenterer forskellige kulturer og traditioner og forskellige former for faglighed. De fire valgte uddannelser dækker tilsammen ca. en fjerdedel af det samlede antal elever, der var i gang med skolepraktik i juni 2010.

Resultaterne viser, at mange elever ikke benytter tilbuddet om skolepraktik efter endt grundforløb. I 2009 var det mellem $15 \%$ og $30 \%$ af eleverne, der ikke fik en praktikplads, som deltog i skolepraktikordningen. Dette hænger sammen med flere forhold: 1) i 2009 var der lukket for adgangen til skolepraktik fra grundforløbet på en række uddannelser, 2) elever, der ikke fik en praktikaftale, valgte at skifte uddannelse, og 3) elever ønskede ikke at tage imod tilbuddet om skolepraktik, dvs., at de ikke søgte om optagelse i skolepraktik.

Dette er interessant, da elever, der tog imod tilbuddet om skolepraktik, er tilfredse med forløbet. Der er flere faktorer, der nævnes i forhold til, hvorfor eleverne ikke søger om optagelse i skolepraktik: skolepraktikkens omdømme, den lave skolepraktikydelse, kravet om mobilitet og vurderingen af, at de ikke har en chance for at få en praktikplads, selvom de tager en periode i skolepraktik. Af resultaterne fremgår det, at der er stor forskel på, hvor længe eleverne er i skolepraktik på de fire uddannelser. På detailhandelsuddannelsen er mere end en tredjedel af eleverne (34 \%) i skolepraktik i mere end halvdelen af tiden. På mekanikeruddannelsen er det en fjerdedel (24\%), der er i skolepraktik mere end halvdelen af tiden. På træfagenes byggeuddannelse og data- og kommunikationsuddannelsen er det en tiendedel (hhv. $9 \%$ og $10 \%$ ), der tilbringer mere end halvdelen af deres tid i skolepraktikken. Trods forskellene mellem uddannelserne viser resultaterne, at eleverne bevæger sig frem og tilbage mellem skolepraktik og praktik i en virksomhed. Hovedparten af skolepraktikeleverne ender altså med at få en uddannelsesaftale.

Endvidere peger resultaterne i retning af, at de relativt få og stærkt svingende antal skolepraktikpladser på de enkelte skoler, gør det vanskeligt for 
skolerne at foretage en mere langsigtet planlægning og gøre en række strategiske valg i forhold til den fortsatte udvikling af skolepraktikken. Konsekvensen er, at det er vanskeligt for skolerne at formulere klare og præcise mål for skolepraktikken og afveje de forskellige mål i tilrettelæggelsen. Skolerne står med meget modsætningsfyldte mål, hvor de på den ene side skal sikre en god uddannelse og høj grad af læring i skolepraktikken samtidig med, at de på den anden side arbejder på hurtigst muligt at få eleverne ud af skolepraktikken og ind i en virksomhedspraktik.

I forhold til læringsudbyttet ses i resultaterne, at skolepraktikken på nogle områder er helt på niveau med en virksomhedspraktik, men på andre områder har vanskeligt ved at give den samme læringsmæssige kvalitet som virksomhederne. Det ses, at eleverne i skolepraktikken i teknisk fagligt forstand har et større læringsudbytte i skolepraktikken, da undervisningen kan tilpasses den enkelte elev. I modsætning hertil står, at skolepraktikken har meget svært ved at etablere et læringsmiljø, som svarer til det, eleverne møder, når de har en praktikplads. Det har den konsekvens, at eleverne ikke socialiseres til arbejdslivet og ikke tilegner sig de arbejdsmæssige kompetencer, som kendetegner den, de er ved at uddanne sig til. De fire uddannelser adskiller sig endvidere fra hinanden i forhold til, hvor let eller vanskeligt det er at finde relevante opgaver til elever i skolepraktikken.

Samlet set viser resultaterne, at skolepraktikken ikke lever op til de potentialer, den har, og kun bidrager i begrænset udstrækning til $95 \%$ målsætningen. Rapporten afsluttes med en række anbefalinger til udviklingen af skolepraktikken:

- Gennemfør forsøg med at samle skolepraktikken på færre lokationer

- Styrk arbejdet med praktikmålene

- Styrk skolepraktikkens omdømme

- Udvid samarbejdet mellem skoler, virksomheder og parterne på arbejdsmarkedet

- Gennemfør forsøg med nye modeller for samspil mellem skolepraktik og praktik i virksomheder. 
I studiet af Jørgensen et al. (2006) undersøges årsager til, at virksomheder, der er godkendte som praktiksteder, ikke opretter praktikpladser. Udgangspunktet for undersøgelsen er på den ene side en permanent mangel på praktikpladser og på den anden side Landsorganisationen i Danmarks (LO) undren over, at mange af de godkendte virksomheder ikke aktuelt har elever. Der blev udvalgt fire forskellige uddannelser til undersøgelsen: Murer, automatiktekniker, kontoruddannelserne og social- og sundhedsassistentuddannelsen.

Undersøgelsen af de fire uddannelser består af to dele. Den første del bygger på en kvalitativ interviewundersøgelse med i alt 35 ressourcepersoner indenfor de fire uddannelser (omkring ni personer indenfor hver uddannelse), dvs. personer fra faglige udvalg, lokale uddannelsesudvalg og skoler samt andre, der har været involveret i praktikpladsopsøgende arbejde eller i analyser af virksomheders forhold til at tage elever. Den anden del af undersøgelsen bygger på en mere kvantitativt orienteret interviewundersøgelse med 50 virksomheder inden for murer-, automatik- og kontoruddannelserne.

På social- og sundhedsområdet var det ikke relevant at interviewe virksomhederne (institutionerne), da alle optagne elever på social- og sundhedsassistentuddannelsen er sikret en praktikplads.

Studiet viser overordnet, at der er mange forskellige årsager til, at de godkendte virksomheder undlader at oprette praktikpladser. Årsagerne er forskellige fra branche til branche, fra fag til fag og fra virksomhed til virksomhed, og de mange forskellige årsager kalder ifølge forfatterne på differentierede løsninger, som tager højde for de enkelte branchers og uddannelsers forhold.

Samlet set viser interviewundersøgelsen med virksomhederne dog, at nogle ting går igen. Flere virksomheder (særligt indenfor automatik) efterlyser et bedre samarbejde med andre virksomheder og med teknisk skole om at uddanne elever. Der peges blandt andet på, at hvis de tekniske skoler i højere grad stod for at koordinere samarbejdet imellem virksomhederne og stod for at kontakte dem, så ville virksomhederne i højere grad være interesserede i at oprette praktikpladser. Indenfor automatikfaget er den væsentlige årsag dog interne ændringer i virksomhederne, idet flere virksomheder oplever, at de er blevet for specialiserede til at have elever i faget. Det vil med andre ord sige, at virksomheden har specialiseret sig på en måde, så det kan være svært at tilbyde 
elever en tilstrækkelig arbejdsmæssig alsidighed og bredde. Problemet med specialisering kan imødegås med en mere aktiv indsats for at udarbejde kombinationsaftaler. Denne ordning kan være en oplagt løsning for især de mindre virksomheder, som ikke tager elever med henblik på rekruttering, men som ser eleven som supplerende arbejdskraft, eller som har en normativ begrundelse for at tage elever. Dog viser studiet, at kun en mindre del af virksomhederne kender til ordningen, og endnu færre har benyttet sig af den.

Særligt indenfor murerfaget giver virksomhederne udtryk for, at skoleforløbene ligger tidsmæssigt forkert, og at de lange skoleperioder forstyrrer produktionen. Der peges især på to forhold: 1) at elevernes uddannelsesforløb burde være mere fleksible, således at mestrene kunne få mere indflydelse på, hvor skoleperioderne passer ind i produktionen, og 2) at skoleperioderne ikke skal ligge i sommerperioden. Inden for det merkantile område (den offentlige sektor) opleves særligt, at forandringsprocesser i form af reformer såvel som besparelser såsom nedskæringer og ansættelsesstop har indflydelse på oprettelsen af praktikpladser og dermed ansættelsen af kontorelever. Derudover angiver en del af virksomhederne, at årsagen, til at de ikke tager flere elever, er mangel på tid og ressourcer. Dette hænger i nogle tilfælde sammen med, at reformerne har resulteret i øget arbejdspres, hvilket går ud over virksomhedernes muligheder for at bruge tid og ressourcer på at lære en elev op. Indenfor den private sektor er omstruktureringer af virksomheden den mest almindelige begrundelse for ikke at have kontorelever, men også her angiver en del virksomheder, at de ikke har tid og ressourcer til at tage sig af oplæring.

Herudover peger undersøgelsen på følgende årsager til, at virksomhederne ikke opretter praktikpladser: For meget administrativt besvær at have elever, eleverne er ikke fagligt dygtige nok, eleverne har ikke tilstrækkelig motivation og disciplin, det er for dyrt at have elever, og virksomheden kan ikke planlægge for de tre år, som uddannelseskontrakterne med eleverne er sat til.

I studiet af Albæk (2005) undersøges, hvilke faktorer der påvirker udviklingen forud for 2005, hvor virksomhederne blev mindre villige til at oprette praktikpladser til erhvervsfaglige elever. Først undersøges det, hvorvidt udviklingen udelukkende kan tilskrives konjunkturudsving i økonomien. Derefter hvilken betydning virksomhedernes omkostninger ved praktikpladser, elever- 
nes produktivitet i praktikpladserne, elevernes aldersgennemsnit, oprettelsen af skolepraktik og størrelsen af ungdomsårgange har for udbuddet af praktikpladser.

Undersøgelsen i studiet bygger på sekundære populationsdata primært fra Dansk Statistik og AER, og der opstilles økonomiske og statistiske modeller til at beregne omkostninger og produktivitet. I analysen anvendes både deskriptiv statistik, variabel modellering og regressionsanalyse. Analysen inddrager også ændringer i relevante kontekstuelle samfundsvilkår.

Studiets resultater viser overordnet, at faldet i praktikplader ikke kan tilskrives økonomiske konjunkturer eller størrelsen på ungdomsårgangene alene. Studiets resultater peger derudover på, at selvom praktikpladselevernes produktivitet synes at være gået op, så er deres gennemsnitlige alder også steget. Både i forhold til alder ved start på uddannelse og praktik samt deres færdiggørelsestid. De omkostninger, virksomhederne har i forhold til at oprette lærepladser er ligeledes steget, hvilket hovedsagligt hænger sammen med udgifter til løn. Netop de stigende omkostninger opfattes af forfatterne som den væsentligste grund til praktikpladsproblemet, og det tilskrives i høj grad virksomhedernes manglende mulighed for frit at kunne regulere elevlønningerne i det danske arbejdsmarkedssystem. Indførelsen af skolepraktik har været omkostningsfuld, og der peges derfor også implicit i denne forbindelse på, at der i stedet burde investeres $i$ at bringe virksomhedernes omkostninger ned, og således, samtidigt, virksomhedernes efterspørgsel efter elever op.

Det anbefales også, at der bliver arbejdet på at bringe gennemsnitalderen for elever ned fra politisk side. Ikke mindst fordi det ikke virker usandsynligt, at tiltag som voksenlærlingeordningen er medvirkende til, at nogle grupper af ansøgere trækker tiden, med henblik på at kunne opnå en højere elevløn efter de er fyldt 25 år.

I Laursen $\mathcal{E}$ Nielsens (2009) studie er formålet med undersøgelsen at identificere en 'best practice' med hensyn til at præcisere, hvilke faktorer der kan bidrage til, at elever fuldfører deres praktikperioder i forbindelse med deres erhvervsuddannelser. 'Best practice' skal her forstås som et funktionelt og hensigtsmæssigt læringsmiljø på praktikstederne. Studiet sætter således fokus på, hvilken betydning læringsressourcer på og omkring praktikstedet har for ele- 
vers læring og deltagelse i et praksisfællesskab i praktikperioderne. Undersøgelsen tager udgangspunkt i interviews med elever og oplæringsansvarlige inden for tre forskellige brancher: mekanik, transport \& logistik, bygge \& anlæg samt service. Inden for hver branche blev der udvalgt ét erhverv: entreprenørog landbrugsmaskinmekaniker, tømrer, og tandklinikassistent. Ud fra disse tre erhverv blev der udvalgt to landbrugs- og maskinvirksomheder, to tømrervirksomheder og to tandklinikker til at deltage i undersøgelsen. Disse seks virksomheder er udvalgt, fordi de i perioden 2000-2008 har haft en fuldførelsesprocent (efter prøvetiden) på minimum 95 \% for de indgåede uddannelsesaftaler mellem virksomheden og eleverne. Data består af i alt 12 interviews, dvs., at én elev og én oplæringsansvarlig fra hver virksomhed er blevet interviewet.

Med afsæt $\mathrm{i}$ en analyse af disse interviews afdækker studiet fem centrale forhold indenfor de tre udvalgte erhverv, der bidrager til en 'best practice' og dermed synes at spille en afgørende rolle for, at eleverne fuldfører deres praktikperiode(r). De fem forhold er følgende:

\section{1) Gensidig udvælgelse fra elevens side og virksomhedens side}

Både oplæringsansvarlige og elever peger på vigtigheden af, at såvel virksomheden som eleven har deltaget aktivt i udvælgelsesprocessen, således at begge parter føler, at de har fundet det rette match. Den gensidige udvælgelse foregår ofte som følge af, at eleven tidligere har arbejdet som arbejdsdreng eller været i 9. eller 10. klasses erhvervspraktik i virksomheden. Herved kender begge parter hinanden allerede inden praktikkens start. Derudover fremhæves det som hensigtsmæssigt, at elevens forældre inddrages i forbindelse med ansættelsessamtalen for også at præsentere dem for de krav, der stilles til eleven i forbindelse med praktikken.

\section{2) Løbende forventningsafstemning mellem mester/svend og eleven inden og under praktikforløbet}

Analysen peger på, at især processen, inden en uddannelsesaftale underskrives, er af stor betydning i forhold til elevens gennemførelse af praktikken. Her er det vigtigt, at der foregår en gensidig afklaring af forventninger mel- 
lem praktikstedet og eleven. Både oplæringsansvarlige og elever påpeger, at denne forventningsafstemning ikke bør slutte, når eleven påbegynder sit praktikophold, men derimod fortsætte gennem hele praktikperioden. Det understreges endvidere, at det er væsentligt, at virksomheden præsenterer både eleven og elevens forældre for virksomhedens holdninger og værdier samt forventninger til eleven med hensyn til faglighed, omgængelighed og samarbejdsvillighed.

\section{3) Hensigtsmæssige læringssituationer på praktikstedet under praktikopholdet}

Resultaterne peger bl.a. på vigtigheden af, at eleven får mulighed for at observere erfarne praktikere udføre faget, ligesom eleven skal have mulighed for at afprøve sine egne færdigheder i forhold til stadigt mere komplekse opgaver. Her understreges betydningen af, at eleven forstår at håndtere rutineopgaver, ligesom han/hun skal være aktivt opsøgende i forhold til udfordrende arbejdsopgaver og bestemte arbejdsområder. Eleven skal ligeledes engagere sig ved at stille krav om at blive inddraget $i$ arbejds- og beslutningsprocesser i virksomheden. Derforuden peger studiet på vigtigheden af, at eleven evalueres, og at han/hun får løbende feedback og anerkendelse fra de mere erfarne fagudøvere på praktikstedet. At eleven arbejder sammen med forskellige svende/fagudøvere, samtidig med at der dannes en stabil arbejdsrelation til en enkelt svend, er ligeledes af stor betydning. En sådan samarbejdsrelation skal være kendetegnet ved tydelig kommunikation, at der stilles krav fra svenden, og at man udviser gensidig interesse og respekt for hinanden. Endvidere understreges vigtigheden af, at elever, som er i praktik i samme virksomhed, gives mulighed for at diskutere faglige problemstillinger med hinanden ud fra de særlige forudsætninger, de har.

4) Personlig støtte til eleven i forbindelse med faglige og personlige problemer i praktikperioden

At eleven inddrages i virksomhedens kultur anses for væsentligt. Det betyder, at eleven for eksempel må tillære sig omgangstonen blandt de ansatte i virksomheden for på den måde at blive en mere fuldgyldig deltager i prak- 
sisfællesskabet. Derudover peger studiet på vigtigheden af, at eleven er tilknyttet én fagligt kompetent person, som han/hun kan tale med om både faglige og personlige problemstillinger. Dette kan blandt andet gøres ved at oprette en form for mentorordning og i den forbindelse tilbyde virksomhedens fagudøvere efteruddannelse i form af for eksempel coaching kurser, som det er blevet gjort i én af de undersøgte virksomheder. Studiet viser, at efteruddannelse af fagudøvere kan bidrage til, at de tager et større ansvar for elevens faglige oplæring og generelle trivsel i virksomheden. Ligeledes påpeges det, at den oplæringsansvarlige skal være tilgængelig for samtaler om personlige forhold og samarbejdsrelaterede aspekter i praktikken.

5) Transfer-og koblingspunkter i elevens bevægelse mellem skoleophold og praktikophold.

Studiet viser, at evalueringer i forbindelse med skoleopholdet (primært i form af en uddannelsesbog, som er udfyldt af underviserne fra erhvervsskolen) er et væsentligt praktisk redskab til at koordinere undervisningen på skolen og oplæringen i praktikken. Eleverne bruger evalueringerne på skolen til at finde ud af, hvilke arbejdsopgaver de skal fokusere på i det efterfølgende praktikophold, ligesom underviserne på erhvervsskolen bruger uddannelsesbogen til at følge op på, hvad eleven har beskæftiget sig med under praktikopholdet. Studiet viser dog også, at en sådan evalueringsform ikke kan stå alene. For at undervisningen på skolen og oplæringen i praktikken opleves som meningsfuld af eleverne, er det afgørende, at der er sammenhæng mellem aktiviteterne i skolesammenhæng og i praktikken, og at der er en overensstemmelse mellem produkttyper, produktmærker og de redskaber, som anvendes begge steder. Derudover viser studiet, at det øger elevernes læringsudbytte på skolen, hvis underviserne inddrager elevernes erfaringer fra praktikopholdet $\mathrm{i}$ undervisningen. Ved at høre om andre elevers erfaringer fra deres praktikophold i undervisningen, får den enkelte elev mulighed for at vurdere og perspektivere sine egne erfaringer fra praktikstedet. Eleverne understreger endvidere vigtigheden af, at mestre/svende eller andre fagudøvere tager aktivt del i det, eleverne lærer på skolen, for at eleverne kan anerkendes som fagpersoner. 


\section{Studiet fra Schweiz}

I studiet (Müller E Schweri, 2007) tages udgangspunkt i, at der i Schweiz har været et fald i andelen af virksomheder med praktikpladser fra $24,7 \%$ af alle virksomheder i Schweiz i 1985 til 17,6 \% af virksomhederne i 2001. Det undersøges hvilke faktorer, der kan forklare dette fald i andelen af virksomheder med praktikpladser.

Undersøgelsen er et longitudinelt studie blandt alle virksomheder i Schweiz, der i 1985, 1995, 1998 og 2001 blev spurgt, hvor mange elever virksomheden havde i praktik i de pågældende år. Data analyseredes kvantitativt for at undersøge de forskellige faktorers forklaringskraft.

En del af faldet $\mathrm{i}$ andelen af virksomheder kan forklares ved forandringer i størrelsen på virksomhederne og sammensætningen af virksomheder. Fra 1985 til 2001 forekom en stigning i nye, små virksomheder, der sjældent opretter praktikpladser. Samtidig er der sket en stigning i andelen af servicevirksomheder, der traditionelt opretter en lavere andel praktikpladser end øvrige virksomheder. Den største del af faldet $i$ andelen af virksomheder med praktikpladser kan forklares ud fra et fald i antallet af 16-årige, og ved at flere unge vælger at tage en gymnasial uddannelse frem for en erhvervsrettet uddannelse. Der er ikke noget i analyserne, der indikerer, at virksomhederne er blevet mere eller mindre interesserede $\mathrm{i}$ at have elever.

\section{Sammenfatning vedrørende skolepraktik og praktikpladser i virksomheder}

Der er fem studier, der undersøger, hvilke faktorer der har indflydelse på faldet i antallet af praktikpladser i virksomheder, og hvilke faktorer der har indflydelse på, at eleverne afslutter deres praktikforløb. Resultaterne af disse studier peger i retning af:

- Elever, der har været i skolepraktik, er generelt tilfredse med forløbet

- Elever i skolepraktik har et større læringsudbytte i teknisk-faglig forstand, da undervisningen kan tilpasses den enkelte elev

- Faktorer, der er medvirkende til, at elever ikke søger om en skolepraktikplads (blot 15-30 \% i 2009): skolepraktikkens dårlige omdømme, lav 
skolepraktikydelse, krav om mobilitet og ønsket om at få en praktikplads i en virksomhed

- Få og stærkt svingende antal af skolepraktikpladser gør det svært for skolerne at udarbejde en langsigtet planlægning og udvikling af skolepraktikken

- Skolerne har ikke klare og præcise mål for skolepraktikken

- Skolepraktikken kan ikke skabe samme læringsmiljø, som svarer til en praktikplads i en virksomhed

- Virksomheder efterlyser et bedre samarbejde med teknisk skole om at uddanne elever, især at det er de tekniske skoler, der skal have ansvaret for at koordinere samarbejdet

- Virksomheder har i højere grad specialiseret sig, hvorfor det kan være vanskeligt at sikre, at eleverne får en tilstrækkelig alsidighed og bredde. Der er et ønske om etablering af en kombinationsmulighed mellem virksomheder

- Praktikforløb burde være fleksibelt tilrettelagt, således at det er den enkelte virksomhed, der bestemmer, hvornår praktikken passer ind i produktionen

- Virksomhederne har manglende tid og ressourcer til at tage sig af oplæring

- Virksomhederne har for meget administrativt besvær, eleverne er ikke dygtige nok, eleverne mangler motivation og disciplin, omkostningerne ved at have praktikpladser er for høje, og vanskelighederne $\mathrm{i}$ at forpligte sig til en treårig uddannelseskontrakt er for store

- Gennemsnitsalderen er steget, hvilket betyder, at elevlønnen er højere

- Virksomhedernes manglende mulighed for at kunne regulere elevlønningerne i det danske arbejdsmarkedssystem

- Virksomheden og eleven skal deltage aktivt i udvælgelsesprocessen, således at både den oplæringsansvarlige og eleven føler, at de har fundet det rette match

- Forældre deltager i ansættelsessamtalen, således at de også skal præsenteres for de krav, der stilles til eleven i forbindelse med praktikken 
- Forventningsafstemning mellem mester/svend/oplæringsansvarlig og eleven inden og under praktikforløbet

- Forældre skal have kendskab til virksomhedens holdninger, værdier samt forventninger til eleven

- Hensigtsmæssige læringssituationer på praktikstedet under opholdet: eleven skal have mulighed for observation af mere erfarne praktikere og for at afprøve egne færdigheder i forhold til stadigt mere komplekse opgaver

- Eleven skal evalueres og løbende have feedback fra de mere erfarne fagudøvere

- Eleverne skal benytte hinanden til at drøfte faglige problemstillinger

- God og stabil samarbejdsrelation til en enkelt svend/oplæringsansvarlig

- Mentorordninger for eleven i forbindelse med faglige og personlige problemer under opholdet. Dette kan gøres ved fx at efteruddanne fagudøvere i coaching

- Eleverne inddrages i virksomhedens kultur og tillærer sig omgangstonen, således at de bliver fuldgyldige deltagere i praksisfællesskabet

- Evalueringer er et væsentligt redskab til at koordinere undervisningen på skolen og oplæringen i praktikken. Evalueringen benytter eleverne til at planlægge, hvilke arbejdsopgaver de skal fokusere på i næste praktikforløb, og underviserne på erhvervsskolerne skal bruge uddannelsesbogen til at følge op på, hvad eleven har lært under praktikopholdet

- Elevernes læringsudbytte øges, når erfaringer fra praktikken inddrages i undervisningen

- Årsagen til det største fald i antallet af praktikpladser i virksomheder i Schweiz skyldes et fald i antal af 16-årige samtidig med, at flere unge vælger at tage en gymnasial uddannelse frem for en erhvervsuddannelse. Fra 1985-2001 sker en stigning i antallet af nye små virksomheder, der sjældent opretter praktikpladser. 


\section{Frafald på erhvervsuddannelserne}

Otte studier indgår i denne kategori. De undersøger, hvilke faktorer der kan medføre frafald, og hvilke tiltag der kan øge gennemførelsen af en erhvervsuddannelse.

Geografisk fordeler studierne sig således: Syv fra Danmark, to fra Holland og et fra Tyskland.

\section{De syv studier fra Danmark}

I studiet af Tanggaard (2013) er formålet at undersøge frafald på erhvervsuddannelserne ud fra elevernes egne refleksioner over og forklaringer på begrebet.

Undersøgelsen er et tværsnitsstudie, hvor 106 elever fra otte erhvervsskoler blev interviewet. Eleverne blev udvalgt på baggrund af tidligere undersøgelser, der identificerede karakteristika ved elever i risiko for frafald, og de interviewede blev udvalgt, så 75 \% af de interviewede kunne betegnes som værende i risiko for at falde fra. Ved interviewene blev eleverne spurgt om deres oplevelser på uddannelsesstedet, deres motivation for uddannelsen og frafald.

Forfatteren identificerede to typer forklaringer på frafald i elevernes fortællinger. Den ene type forklaringer var systemorienterede forklaringer. Her beskrev eleverne, hvordan det lave antal lærere per elev mindskede engagementet, og at særligt de elever, der ikke havde en praktikplads, fik mindre tid med lærerne, da de havde længere tid til at gennemføre kurserne. Ligeledes blev manglen på praktikpladser og problemerne med at finde en plads fremhævet, og eleverne beskrev, at de stærkeste elever blev hjulpet til praktikpladser frem for de svage elever. Forfatteren tolker disse forklaringer som udtryk for en selektionsproces knyttet til erhvervsuddannelsessystemet, hvor de stærkeste tildeles fordele, hvilket kan føre til frafald for de svageste elever.

Den anden type forklaringer retter sig mod manglende motivation og initiativ fra de frafaldne studerendes side. Her individualiseres frafaldet og anses som et problem for den enkelte elev. Disse typer forklaringer kobles med coaching og psykologhjælp, der ifølge forfatteren er de mest udbredte strategier mod frafald på erhvervsuddannelserne. Forfatteren vurderer, at disse strategier er med til at understøtte synet på frafald som et individuelt problem. 
På baggrund heraf konkluderes, at det kan være nødvendigt at udforme strategier mod frafald relateret til ændringer af uddannelsesmiljøerne og det sociale miljø frem for kun strategier, der individualiserer frafaldet, samt at der bør lyttes mere til eleverne og deres syn på, hvad der udgør god undervisning og læring.

Forskningsprojektet "Fastholdelse af erhvervsskoleelever i det danske erhvervsuddannelsessystem" (Nielsen et al., 2013) har til formål at undersøge de påvirkelige faktorer, som kan bidrage til at mindske frafaldet på de erhvervsfaglige uddannelser. Projektet har fokus på tiltag og indsatser, der kan hindre frafald, samt andre forhold på individ- eller arbejdsmarkedsniveau, der kan påvirke frafald. Projektet er igangsat af erhvervsskolerne.

Projektet kombinerer kvantitative og kvalitative metoder, hvor den kvantitative del søger at belyse, hvor gode eller mindre gode erhvervsskolerne er til at fastholde eleverne, samtidig med at den tegner et billede af de unge, som er i risiko for at falde fra en erhvervsuddannelse. Denne del af undersøgelsen er baseret på data fra PISA-Longitutional, testdata, surveys og registerdata fra Danmarks Statistik. På baggrund af projektets kvantitative analyser er otte skoler udvalgt til deltagelse i den kvalitative del af projektet. Det drejer sig om fire skoler med højt frafald og fire skoler med lavt frafald. I den kvalitative del er der gennemført strukturerede interviews med 108 erhvervsskoleelever (hvoraf 52 blev geninterviewet), 30 lærere og ti skoleledere på de otte skoler. De deltagende elever er primært elever, som af erhvervsskolerne er vurderet som frafaldstruede. Efterfølgende blev der udført to større dataundersøgelser (en skoleundersøgelse og en aktivitets- og holdundersøgelse) af de nye grundforløbspakker iværksat på erhvervsskolerne som følge af erhvervsskolereformen fra 2007. Til aktivitets- og holdundersøgelsen er der anvendt registerdata fra erhvervsskolernes administrative database "Easy" og fra Danmarks Statistik, mens der i skoleundersøgelsen er gennemført interviews med uddannelsesansvarlige og administrativt personale på 18 skoler med tekniske erhvervsuddannelser. Derudover er 15 andre erhvervsskoler blevet kontaktet telefonisk med henblik på at beskrive hvilken indretning af grundforløbene, de benytter.

Undersøgelsen viser, at der er mange, forskellige grunde til, at eleverne i en erhvervsuddannelse falder fra. Dette peger på, at frafaldsfænomenet ikke 
alene kan forstås gennem individuelle forhold ved eleverne, men at frafald også sker som konsekvens af sociale, organisatoriske og strukturelle forhold. Resultaterne peger derved på, at indsatser mod frafald også må differentieres og målrettes efter de særlige grunde, eleverne har til at falde fra. I undersøgelsen peges både på faktorer på arbejdsmarkedsniveau, faktorer på institutionsniveau og faktorer på individniveau, der kan bidrage til at mindske frafaldet på erhvervsuddannelserne.

\section{Faktorer på arbejdsmarkedsniveau:}

Undersøgelsen peger på, at ungdomsarbejdsløshedspakken, som blev indført i 1996 med yderligere tiltag i 1998/1999, kan have haft betydning for de unges beslutninger vedrørende valg af uddannelse efter grundskolen, og at dette kan have haft betydning for frafaldet. Ungdomsarbejdsløshedspakken havde som formål at tilskynde unge under 25 år uden uddannelse til at påbegynde en uddannelse, og efter at ungdomsarbejdsløshedspakken blev indført, steg antallet af unge, der påbegyndte en ungdomsuddannelse. Undersøgelsen viser imidlertid, at frafaldet på ungdomsuddannelserne steg i samme periode, hvilket indikerer, at de unge, der tidligere havde mulighed for at bruge mere tid til at blive afklaret, modnet eller få erhvervserfaring, i stedet følte sig tvunget til at tage en uddannelse, og at dette i sig selv kan have medført, at det registrerede frafald i samme periode steg.

Vedrørende praktikpladser viser undersøgelsen, at de elever, som har en praktikplads inden grundforløbets begyndelse, i højere grad gennemfører deres uddannelse, og i det hele taget spiller praktikpladser en væsentlig rolle i forbindelse med frafaldsproblematikken. Elever, der havde en praktikplads, oplevede dette som noget, der fastholdt dem i uddannelsesforløbet, ligesom en del elever koblede frafald med manglende praktikplads. Kun et fătal af de interviewede elever overvejede seriøst at tage en skolepraktik, og et flertal afviste skolepraktikken af såvel økonomiske som faglige grunde. Desuden viser undersøgelsen, at graden af støtte til eleverne i forbindelse med praktikpladssøgninger varierede meget fra lærer til lærer, fra fag til fag og fra skole til skole. Endvidere er der en tendens til, at elever, der får en praktikplads, har et stærkt socialt netværk via familie eller venner. 


\section{Faktorer på institutionsniveau:}

Undersøgelsen viser, at der er forskel på erhvervsskoler i forhold til, hvor gode eller mindre gode de er til at fastholde deres elever, selv efter der er taget højde for elevkarakteristika på tværs af uddannelsesinstitutioner. Påvirkelige forhold i undervisnings- og skolemiljøet kan være med til at forklare forskellene i skolernes resultater. Det vil med andre ord sige, at både direkte tiltag og indsatser, som skolerne iværksætter mod frafald, og mere generelle forhold på skolerne som for eksempel skoleledelse og lærerkompetencer, kan spille en stor rolle for erhvervsskolernes frafald.

Derudover viser interviewundersøgelsen, at især eleverne på de tekniske skoler foretrækker værkstedsbaseret undervisning, og det fremhæves, at det er i hverdagens arbejde i værkstederne, at elevernes skolemæssige motivation og engagement styrkes. Undersøgelsen peger på, at nogle fastholdelsesinitiativer har den modsatte effekt af, hvad der er tiltænkt. Det gælder for eksempel den obligatoriske kompetencevurdering, som foretages og anvendes for at afdække elevernes kompetencer, og for at finde det rette tilbud til den enkelte elev i uddannelsessystemet. Resultaterne peger i retning af, at kompetencevurderingen bruges til at frasortere "de svageste" elever, hvilket betyder, at nogle elever "bortvejledes". Dette skyldes bl.a., at det er svært for lærerne at gennemføre undervisningen med så høje klassekvotienter. En af konsekvenserne ved taxametersystemet kan således være et kalkuleret frafald fra undervisernes side.

I undersøgelsen af grundforløbspakker iværksat på erhvervsskolerne identificeres to hovedmodeller med tidlig og sen opdeling af elever: Det ene model benævnes "clear cut"'-modellen, hvor eleverne fra starten af uddannelsen er inddelt i forskellige klasser efter niveau, hvilket medfører, at elever med få ressourcer ikke går sammen med de mere ressourcestærke elever. I den anden model, "vent-og-se"-modellen, begynder alle elever, uanset forudsætninger, på samme hold, og de sorteres først, når elever, der ikke formår at gennemføre inden for de første 20 uger, identificeres. Undersøgelsen viser, at eleverne i gennemsnit falder fra senere og har et lavere frafald på skoler, hvor "vent-og-se"modellen anvendes, sammenlignet med skoler, hvor "clear-cut"-modellen anvendes. 


\section{Faktorer på individniveau:}

Den kvalitative interviewundersøgelse viser, at langt størstedelen af eleverne har foretaget et positivt valg af deres erhvervsuddannelse, og de har således en interesse for den uddannelse, de er begyndt på og et ønske om et specifikt erhverv. Dette gælder i mindre grad for elever på HG, hvor elevernes valg af uddannelse er et negativt valg, hvor uddannelsen ses som et venterum, en afklaringsperiode eller en mulighed for at forbedre skolekundskaber. Men frafaldet på HG er lavere end på de tekniske skoler, hvilket til dels modsiger forfatternes tese om, at et positivt valg af uddannelse mindsker risikoen for frafald.

I Jensen $\mathcal{E}$ Larsen (2011) undersøges, hvilke værdier, interesser og holdninger unge, der gennemførte en erhvervsuddannelse, havde sammenlignet med unge, der ikke gennemførte.

Rapporten har et longitudinalt design og bygger på data fra PISAundersøgelsen fra 2000, hvor elever fra årgangene 1983 og 1984 fik testet deres færdigheder, ligesom de besvarede et spørgeskema om deres skolegang og forældrebaggrund. Fire år senere - i 2004 - besvarede de unge et spørgeskema om valg af uddannelse, interesser i forhold til arbejdslivet samt syn på og holdninger til uddannelse. Derudover indgår en lang række registeroplysninger om de unges vej gennem uddannelsessystemet og ud på arbejdsmarkedet frem til og med 2008. I analyserne undersøges sammenhængene mellem disse forhold, og der inddrages en række baggrundsfaktorer, således at det kan vurderes, hvorvidt de unges begrundelser, interesser og holdninger spillede en selvstændig rolle for de unges adfærd efter grundskolen.

Undersøgelsen viser, at de unge, der begrundede deres valg af uddannelse efter grundskolen med, at de var skoletrætte, og at de havde behov for at tjene penge, havde større risiko for at afbryde deres erhvervsuddannelse sammenlignet med de mindre skoletrætte. Samtidig viser undersøgelsen, at de unge, der begrundede valg af uddannelse med positive erfaringer fra erhvervspraktik, faglige interesser og fremtidige beskæftigelsesmuligheder, var mindre tilbøjelige til at afbryde deres uddannelse. Undersøgelsen viser også, at de unge på de tekniske erhvervsuddannelser, der fuldførte deres uddannelse, i højere grad end de unge, der afbrød deres uddannelse, lagde vægt på, at de ønskede at arbejde med teknik/håndværk og praktisk/fysisk arbejde. Tilsvarende lagde de 
unge på de merkantile erhvervsuddannelser, der fuldførte deres uddannelse, i højere grad end de unge, der afbrød deres uddannelse, vægt på, at de ønskede at arbejde med handel og penge. Undersøgelsen indikerer dermed, at de interesser, de unge har i forhold til deres arbejdsliv, fremmer deres chancer for at gennemføre, såfremt disse interesser falder sammen med indholdet $i$ den valgte uddannelse. Ifølge forfatterne peger dette på, at det er vigtigt, at uddannelsen formår at engagere og motivere de unge i forhold til fremtidige beskæftigelsesmuligheder. Videre pointeres det, at det er væsentligt, at erhvervsskolerne formår at udnytte de unges interesser for faget, som også en del af de unge, der afbrød uddannelsen, havde som drivkraft til at motivere eleverne.

Samtidig fremgår det, at de unge, der gennemførte deres uddannelse, i højere grad end de unge, der afbrød, angav, at de havde et godt overblik over relevante muligheder ved valg af uddannelse. Forfatterne anbefaler derfor, at der tilbydes mere uddannelses- og erhvervsvejledning med fokus på job- og karrieremuligheder.

Danmarks Evalueringsinstitut (2013) har udarbejdet en evaluering af årsager til frafald på erhvervsskolerne SOPU, der udbyder uddannelser inden for sundhed, omsorg og pædagogik i København og Nordsjælland. Formålet med undersøgelsen var at identificere forhold vedrørende frafald, der enten havde med skolen at gøre, eller som skolen ville kunne påvirke.

Undersøgelsen er et casestudie af sundhedshjælperuddannelsen og sundhedsassistentuddannelsen på SOPU i Hillerød og København og bygger på interviews med 20 frafaldne elever og interviews med ti elever, der fortsat gik på uddannelserne. Derudover blev gennemført fokusgruppeinterview, telefoninterview og en workshop med pædagogiske medarbejdere fra SOPU og uddannelsesvejledere fra Hillerød Kommune og København Kommune.

Undersøgelsen peger på, at frafaldsbilledet er komplekst, men overordnet er der to forhold, der fremhæves som særligt betydningsfulde for elevernes frafald. Det ene forhold er læringsmiljøet og arbejdsformerne på skolen. Flere elever fremhævede, at de godt kunne lide lærerstyret tavleundervisning frem for gruppearbejde uden tydelige mål. Gruppearbejdet var både en udfordring for de introverte og socialt udfordrede elever og for de stærke elever, der oplevede et lavt fagligt niveau i gruppearbejdet. 
Det andet forhold er praktikopholdet, under hvilket flere elever faldt fra af forskellige grunde. Især fremhæves, at elevernes forventninger til praktikopholdet ikke stemte overens med deres oplevelser i praktikken. Eleverne oplevede, at deres idealer om omsorg ikke stemte overens med de kommunale krav om effektivitet. Ofte dumpede eleverne på grund af dette og faldt derfor fra. Det anbefales derfor, at eleverne i højere grad forberedes på, hvad de går ind til i praktikken, og at opstarten i praktik gøres blødere, ved at eleverne kommer i praktik i par eller mindre hold. Flere interviewede gav udtryk for, at der manglede sammenhæng mellem praktik og skole, og at SOPU i mindre grad end andre erhvervsskoler holder kontakt med eleverne undervejs i elevernes praktikforløb.

I Højmark E Jørgensen.s (2005) undersøgelse er formålet at belyse og analysere etniske minoritetsunges oplevede barrierer for at fuldføre en erhvervsuddannelse. Etniske minoritetsunge defineres i denne undersøgelse som unge, hvis forældre er født i ikke-vestlige lande. Der undersøges barrierer på individniveau, uddannelsesinstitutionsniveau og samfunds/arbejdsmarkedsniveau.

Undersøgelsen er en tværsnitsundersøgelse, hvor der er gennemført kvalitative interviews med 12 frafaldne minoritetsunge, med seks etniske minoritetsunge, der klarer sig godt på erhvervsuddannelserne, med seks etnisk danske unge under uddannelse, med seks forældre til frafaldne, med seks nøglepersoner på virksomheder og med seks studievejledere. I alt blev gennemført 42 interviews, ligesom forfatterne har gennemført tre workshops om frafald og tre observationsstudier med fokus på arbejdsformer, læreprocesser og relationer. Den indsamlede empiri er ligeligt indsamlet på drengedominerede uddannelser, pigedominerede uddannelser og uddannelser med en lige kønsmæssig fordeling. I undersøgelsen skitseres tre forklaringer på de etniske minoritetsunges frafald på erhvervsuddannelserne, og hvad der kan gøres for at forhindre frafald i forhold til hver af de tre forklaringer.

Den ene forklaring vedrører, at en meget stor gruppe af de etniske minoritetsunge oplevede, at der var et begrænset udbud af praktikpladser, at de havde svært ved overhovedet at komme i betragtning til en praktikplads, og at de derfor faldt fra. Undersøgelsen indikerer, at manglen på praktikpladser rammer de etniske minoritetsunge hårdere end de etnisk danske unge, og at det er op- 
fattelsen på virksomhederne, at ansættelse af etniske minoritetsunge er forbundet med ekstraomkostninger. På baggrund heraf vurderer forfatterne, at økonomiske incitamenter kan få virksomhederne til at antage flere etniske minoritetsunge. Forfatterne peger også på, at virksomhederne foretrækker elever, som er anbefalet af folk fra uddannelsesinstitutionerne, og at dette kan være en mulighed for de etniske minoritetsunge for at få en praktikplads. Endelig peger undersøgelsen på, at de etniske minoritetsunge opfattede skolepraktik som et reelt og væsentligt alternativ til virksomhedspraktikken, og skolepraktik kan dermed være et redskab til at mindske de etniske minoritetsunges frafald.

Den anden forklaring på frafaldet er, at flere etniske minoritetsunge faldt fra deres erhvervsuddannelse, fordi de oplevede, at det faglige niveau var for højt. De etniske minoritetsunge gav i interviewene udtryk for, at deres svagere sproglige og faglige udgangspunkt var en hæmsko for at tage del i undervisningen, hvilket gjorde det sværere at følge med. Dette kan ifølge forfatterne skabe barrierer i forhold til at etablere samarbejdsrelationer til de fagligt stærke elever og til de etnisk danske elever. De etniske minoritetsunge var positive over for blanding af eleverne, og forfatterne peger på, at arbejdsgrupper konstrueret af lærerne kan være en måde at stimulere de sociale og faglige relationer mellem eleverne på. Samtidig oplevede de etniske minoritetsunge (og etnisk danske unge) mange af fagene på erhvervsuddannelserne som teoritunge og enkelte fag som uvedkommende i forhold til den kommende profession, hvilket ifølge de frafaldne unge førte til en faldende motivation, særligt for de svageste elever. I relation hertil foreslog nogle studievejledere, at de faglige krav i de mest teoritunge fag blev sænket.

Den tredje og sidste forklaring på de etniske minoritetsunges frafald var, at erhvervsuddannelserne var præget af korte og opsplittede forløb med mange valgmuligheder for sammensætning af fag, hvilket var medvirkende til, at de etniske minoritetsunge oplevede, at uddannelsesforløbet var uoverskueligt. Hertil kommer, at de unge sjældent fik oplevelsen af gruppeidentitet på uddannelsesforløbet. Forfatterne peger her på, at kontaktlærere har en vigtig rolle i forhold til at skabe en rød tråd i uddannelsesforløbet og holde fast i de etniske minoritetsunge. 
Forfatterne finder, at de etniske minoritetsunge, der falder fra, ikke er nogen homogen størrelse, og de konstruerer fire grupper af etniske minoritetsunge, der har forskellige barrierer i forhold til gennemførelse.

Eleverne i den mest udsatte gruppe har såvel faglige, sproglige som sociale problemer, som de står alene med. Tiltagene skal derfor målrettes mod at løfte det faglige niveau og sikre en social forankring på uddannelsesinstitutionerne (for eksempel ved danskundervisning for tosprogede, lektiecaféer, mentorordninger/konstruerede arbejdsgrupper) ved at arbejde med den unges selvværd og identitetsudvikling (for eksempel gennem en velfungerende kontaktlærerordning eller ved at have sociale aktiviteter på skolen og i klassen/på holdet).

Den anden gruppe elever er kendetegnet ved, at de har faglige problemer i nogle fag og ikke helt mestrer nuancerne i det danske sprog. De hører ikke til blandt den fagligt dygtigste gruppe af elever og har derfor også ekstra svært ved at få en praktikplads. Netop denne gruppe er glade for at gå i skolepraktikordningen, da alternativet ofte vil være, at de ikke kan gennemføre deres uddannelse. Det anbefales, at indsatser i forhold til denne gruppe retter sig mod at løfte deres faglige niveau i bestemte fag (for eksempel gennem lektiecaféer og tilbud om faglig støtte), støtte til nuancering af det danske sprog og netværksdannelse på uddannelsesinstitutionerne (for eksempel danskundervisning til tosprogede, mentorordninger, velfungerende kontaktlærer/studievejlederordning eller sociale aktiviteter på skolen og i klassen/på holdet) og støtte til praktikpladssøgning (for eksempel hjælp til at skrive ansøgninger, mulighed for skolepraktik og støtte fra institutionen til at få en praktikplads).

Den tredje gruppe elever er kendetegnet ved, at de klarer sig godt på erhvervsuddannelserne fagligt set, om end de har problemer med nuancerne i det danske sprog. De centrale barrierer for denne gruppe elever er, at de ikke kan få en praktikplads, og at deres danske netværk er meget begrænset, og at de derfor har nogle problemer med det danske sprog. Indsatser i forhold til denne gruppe kan være støtte til nuancering af det danske sprog, netværksdannelse på uddannelsesinstitutionerne samt støtte til praktikpladssøgning.

Eleverne i den sidste gruppe er veltilpassede og velintegrerede unge. Når de falder fra, er det oftest, fordi de ikke kan få en praktikplads. Nogle af dem er, 
ligesom mange etnisk danske unge, søgende i forhold til at være sikre på, om deres uddannelse lever op til deres forventninger, og i denne proces er det ifølge forfatterne vigtigt, at erhvervsuddannelserne giver de unge nogle faglige og sociale udfordringer, samt at de unge har adgang til vejledning. Indsatser i forhold til at sikre, at de veltilpassede etniske minoritetsunge får en uddannelse, kan være at yde støtte i forhold til praktikpladssøgning, at give de unge faglige og sociale udfordringer på erhvervsuddannelserne (for eksempel sociale aktiviteter på skolen og uddannelsesvejledning) og at give de unge en målrettet studievejledning (for eksempel ved at de unge har adgang til en studievejleder, der kender dem).

En anden undersøgelse fra 2005 (Jensen \& Jensen, 2005) har til formål at belyse, hvorfor nogle unge ikke gennemfører en ungdomsuddannelse. Det undersøges hvilke forhold, som er af særlig stor betydning for, om unge uden ungdomsuddannelse kommer i gang med en uddannelse - og fuldfører den.

Undersøgelsen består af flere delundersøgelser, hvor den ene er en tværsnitsundersøgelse, hvor 49 unge mellem 16 og 24 år, der ikke havde en ungdomsuddannelse eller var i gang med en, blev interviewet. Gennem interviewene har forfatterne søgt at belyse og forstå de unges livsverdener og på baggrund heraf konstrueres fire profiler af unge, og der gives forslag til, hvad der ville kunne virke motiverende $i$ forhold til at gå i gang med en ungdomsuddannelse for hver af de fire profiler. De fire profiler er konstrueret på baggrund af graden af de unges kulturelle kapital (forstået som graden af forældrenes uddannelsesorientering, støtten til de unge, den unges kompetencer og tro på sig selv) og de unges sociale kapital (forstået som sociale kompetencer, relationer og opvækstforhold) set i relation til de øvrige unge. Yderligere er i en anden del af undersøgelsen blevet gennemført workshops på tre erhvervsuddannelsesinstitutioner og gennemført interviews med elever, der var i gang med en gymnasial uddannelse, med elever der var i gang med en erhvervsuddannelse og med elever, der var faldet fra en erhvervsuddannelse.

Overordnet finder forfatterne, at det er attraktivt for de unge, hvis begge køn er repræsenteret på uddannelsesinstitutionerne, og hvis uddannelsesinstitutionerne ligger i nærheden af de unges "gå i byen-miljøer". For de etniske minoritetspiger er det vigtigt, at der på uddannelsesinstitutionen er nogle 
rammer, der muliggør, at de kan sidde og lave lektier alene eller sammen med deres gruppe, og at de har et sted at mødes med andre unge, også i fritiden. Vedrørende praktikpladssøgningen anbefaler forfatterne, at ansvaret for at finde praktikpladser ikke bør overlades til eleverne alene. Eleverne skal tilbydes hjælp til at udforme ansøgninger, skolerne skal have kontakt til virksomhederne og anbefale de unge, ligesom der bør være mulighed for prøvepraktikperioder og vikarordninger.

Da de unge ikke er en ensartet gruppe, præsenteres resultater og anbefalinger for hver af de fire profiler af unge. Nogle af de unge ville ifølge forfatterne kunne indgå i det eksisterende uddannelsessystem, hvis de fik lidt støtte og vejledning, mens der er andre, som har brug for en massiv indsats på flere områder.

I den ene profil er unge med både en lav grad af kulturel kapital og en lav grad af social kapital. De unge i denne gruppe har typisk følt sig dårligt tilpas i skolen og haft det svært med det faglige niveau, de făr ikke nogen støtte fra familien og har ikke noget socialt netværk. For at de unge i denne gruppe skal kunne gennemføre en uddannelse, anbefaler forfatterne, at det teoretiske stof skal være snævert knyttet til det praktiske arbejde, og det praktiske skal være indgangen til uddannelsesforløbet. Videre skal der også foranstaltes personlige støttemuligheder gennem eksempelvis en vejleder, der støtter de unge under hele uddannelsesforløbet.

De unge i den anden profil har en lav grad af kulturel kapital, men en høj grad af social kapital. De unge i denne gruppe har typisk et stærkt socialt netværk, men de har ikke haft den store succes i skolen. For at de unge i denne gruppe skal kunne gennemføre en uddannelse, anbefaler forfatterne, at det teoretiske stof er snævert knyttet til det praktiske arbejde, og at det praktiske skal være indgangen til uddannelsesforløbet. Der skal også være tilknyttet en vejleder, der sammen med familien holder de unge fast i forløbet, og der skal være sociale arrangementer på uddannelsesinstitutionen.

De unge i den tredje profil har høj grad af kulturel kapital, men lav grad af social kapital. De har haft faglig succes i skolen, men har ofte ikke et stort socialt netværk. Frafald forklares for unge i denne gruppe oftest med, at de unge er i en socialt marginaliseret position med få venner og støttepersoner, og de har 
derfor brug for tryghed og fællesskab, der knytter dem til uddannelsesinstitutionen. Forfatterne anbefaler, at det teoretiske stof afstemmes efter den enkeltes tempo og formåen, men der må gerne være tilknyttet større teoretiske blokke til uddannelsen. Det anbefales også, at der er tilknyttet en vejleder til de unge, der kan give støtte og vejledning, ligesom der skal være sociale arrangementer på uddannelsesinstitutionen.

De unge i profilen med både høj kulturel og social kapital har gode sociale kompetencer og har klaret sig relativt godt i skolen fagligt set. De unge i denne gruppe er oftest gode til de teoretiske studier, men de har mere lyst til uddannelsesforløb, hvor de anvender deres kreative kompetencer. Forfatterne anbefaler, at disse unges uddannelsesforløb er individuelt tilrettelagte, og at forløbene giver muligheder for kreative udfoldelser eller anden ikke boglig aktivitet, ligesom der skal være sociale aktiviteter, der bidrager til at fastholde de unges engagement.

Katznelson (2007) har foretaget en evaluering af en række tiltag, der har som formål at øge gennemførelsesprocenten for frafaldstruede elever på Erhvervsuddannelsescenter Syd (EUC Syd). De fire tiltag, der evalueres, er:

- Niveaudeling på erhvervsuddannelsernes grundforløb, hvor der på nogle uddannelser er etableret et indslusningsforløb i form af en særlig linje målrettet elever med særlige behov for støtte eller afklaring til valg af uddannelse. Opdragelsesmæssige og sociale mål står i centrum på indslusningsforløbet, og eleverne starter med at udøve deres håndværk med det samme i modsætning til på grundforløbet, hvor dette først sker senere.

- En screeningstest af alle elever ved optag, som har til formål at hjælpe erhvervsskolen med at afdække den enkelte elevs profil og teste elever, der vurderes at have vanskeligheder og behov for støtte. Testen anvendes også til at inddele eleverne i indslusningsforløbet og et ordinært grundforløb.

- En "streetworker", som tager sig af udsatte elevers trivsel i uddannelsen gennem individuel kontakt til elever med behov for særlig støtte.

- Et psykologtilbud, der dækker alle ungdomsuddannelser i det daværende Sønderjyllands Amt. Omkring to tredjedele af psykologernes tid bruges på 
individuel samtaleterapi, mens den resterende tid bruges på kurser og vejledning af undervisere og vejledere.

Rapporten anvender et casestudiedesign på to uddannelsesafdelinger under EUC Syd. En tredjedel af de optagne elever på EUC Syd vurderes at have behov for en ekstra indsats fra uddannelsesinstitutionens side. 15 elever og 14 undervisere og ressourcepersoner blev interviewet, ligesom der blev foretaget feltobservationer.

Rapportens resultater er udformet i en række anbefalinger til EUC Syd. Overordnet anbefales, at frafaldsstrategien ikke alene hviler på de fire tiltag, men at den i lige så høj grad inddrager det eksisterende lærerkorps og sikrer, at deres kvalifikationer og arbejdsvilkår gør det muligt at sætte ind over for frafaldet i hverdagen. Det anbefales også, at EUC Syd gør andre instanser med afgørende indflydelse på elevernes trivsel i uddannelsen (eksempelvis kommunen) opmærksomme på eventuelle problemstillinger i relation til eleverne.

Det anbefales at indføre et indslusningsforløb på alle uddannelser, som er rettet mod elever, der har behov for en særlig indsats for at gennemføre. Linjen skal have et mere fast struktureret forløb end det ordinære grundforløb, ligesom der skal skabes nogle stabile rammer og formuleres klare læringsmål for og med eleverne. Kompetencekravene for overgang til det ordinære forløb skal tydeliggøres.

Screeningen giver lærerne et redskab til at vurdere, hvilke uddannelsesmæssige behov de forskellige elever har allerede fra starten af, og dermed også muligheden for at sætte hurtigt og effektivt ind over for mulige problemer. Det anbefales derfor, at eleverne screenes ved uddannelsesstart, og yderligere anbefales, at resultatet af testen danner udgangspunkt for tilrettelæggelsen af individuelle pædagogiske handleplaner for de udsatte elever.

Videre anbefales det, at der etableres en akuttjeneste til håndtering af sociale og andre akut opståede problemer i relation til elevernes trivsel generelt og på uddannelserne. Tjenesten skal være koblet til flere personer, så funktionen bliver strukturel og professionel frem for personlig, og samtidig skal arbejdet med elevernes problemer ikke overlades til lærerne. I forlængelse heraf fremhæves psykologtilbuddet særligt, idet det virker fremmende for elevernes inte- 
gration i uddannelsen og deres generelle trivsel. Det anbefales derfor, at dette tilbud udvides og tilføres flere midler, eller at der sker en opprioritering af de elever, som vurderes at have størst og mest akut behov for hjælp. Endelig anbefales, at samarbejdet mellem psykologerne og lærerne styrkes i forbindelse med kompetenceudviklingen af lærerne, så de kan løfte opgaven med at håndtere udsatte elever.

\section{De to hollandske studier}

I studiet af Hofman \& Hofman (2011) undersøges, hvordan forskellige ledelsesstrategier påvirker elevernes resultater i matematik på erhvervsskoler $\mathrm{i}$ forhold gymnasiale uddannelser i det hollandske uddannelsessystem. Fire ledelsesstrategier bliver undersøgt: 1) gensidig tilpasning mellem skolens ledelse, lærerne og elevernes forældre $\mathrm{i}$ form af inddragelse i og høring $\mathrm{i}$ forbindelse med ledelsens beslutningsprocesser samt tilpasning til den måde, skolen bliver ledet og kørt på, 2) supervision af lærernes undervisning, 3) standardiseret undervisning og måling af elevernes output og 4) strømlining og standardisering af skolens organisation, værdisæt, koordination og det professionelle niveau blandt de ansatte.

Studiets undersøgelsesdesign er longitudinelt, og der indgår 3.886 elever heraf 2.805 fordelt på 121 gymnasiale uddannelsesinstitutioner, og 1.081 fordelt på 56 erhvervsskoler. Data blev indsamlet via spørgeskemaer udelt til lærere, elever, forældre og skolens ledelse. Disse data blev koblet til baggrundsdata fra skolernes registre $\mathrm{i}$ form af resultater i matematik og data om elevernes intelligens, etnicitet, skolernes demografiske placering og en række andre relevante socioøkonomiske forhold. Data blev analyseret gennem klyngeanalyse og statistisk mulitlevel-analyse i tre niveauer.

Studiets resultater peger overordnet på, at elever på erhvervsuddannelser i højere grad bliver påvirket af forskellige ledelsesstrategier end elever på gymnasiale uddannelser, i forhold til resultater i matematik. Resultaterne peger især på, at supervision og optimering af lærernes undervisning samt gensidig informationsudveksling og tilpasning mellem lærere, ledelse og (i særdeleshed) forældre har en mere positiv virkning på erhvervsskoleelever end på elever fra gymnasiale uddannelser. De samme typer forskelle blev fundet i forhold til monitorering af elevernes output. 
Studiets resultater indikerer samlet, at elever på erhvervsskoler har større udbytte af ledelsesstrategiske tiltag end elever på gymnasier, især i forhold til inddragelse af forældre, lydhørhed mellem skolens ansatte og ledelsen, samt af, at skolens ledelse har forventninger til elevernes og lærernes præstationer i undervisningen og gennemfører supervision af lærere og løbende måler elevernes resultater.

I det andet hollandske studie (Cabus \& De Witte, 2010) undersøges, hvorvidt der er en effekt ved, at den obligatoriske skolealder er blevet udvidet med et år i Holland som led i 'kvalifikationsloven' fra 1. august 2007. Den nye lov betyder, at eleverne ikke længere kan forlade skolen på deres 17-års fødselsdag, men derimod først når de har fået et ungdomsuddannelsesbevis, eller når de fylder 18 år.

Studiet har til formål at undersøge, hvorvidt der er en sammenhæng mellem et års udvidet undervisningspligt frem til og med elevens 17. år og undervisningspligtens virkning på frafaldet på ungdomsuddannelser.

Evalueringen af den nye lovs virkning sker ved, at elever, der er omfattet af undervisningsreformen, og som er født efter 1. august 1990, fungerer som eksperimentgruppe og elever født før 1. august 1990 og 1989 fungerer som kontrolgruppe. Der tages altså højde for variation $i$ forhold til forårs/efterårssemestre samt effekter fra elevernes forskellige alder.

Gennem forskellige analyser undersøges det, hvorvidt frafaldet reduceres gennem et års udvidet undervisningspligt til eleven fylder 18 år. Data udgøres af to forskellige statistiske registerdata. Undersøgelsen anvender registerdata på alle elever i Holland hentet fra det hollandske undervisningsministerium (BRON-data), hvori det er registreret, hvorvidt en elev fortsætter i en ungdomsuddannelse. Disse data kombineres med registerdata på kommunalt niveau i Amsterdam, hvori detaljerede baggrundsinformationer om eleverne, for eksempel deres socioøkonomiske baggrund, er registreret. Disse data kombineres og analyseres i studiet.

Analysen er udformet således, at data på elever, der er omfattet af reformen, sammenholdes med data på elever, der ikke er omfattet af reformen.

Overordnet viser studiet, at der er en sammenhæng mellem et års udvidet undervisningspligt og frafald på ungdomsuddannelserne. Frafaldet på ungdoms- 
uddannelserne reduceres med 2,5 procentpoint, når undervisningspligten udvides med et år. Dette resultat skal dog læses med forsigtighed, da der ses en usædvanlig stigning i frafaldet blandt de 17-årige elever i kontrolgruppen, der ikke var omfattet af undervisningsreformen og dermed det ekstra undervisningspligtige år. Dette kan ifølge forfatterne hænge sammen med ydre forhold såsom et økonomisk opsving, der medførte et stort behov for både faglært og ufaglært arbejdskraft. Den store stigning i frafaldet skal derfor ses i sammenhæng med stigningen $\mathrm{i}$ antallet af ledige stillinger for helt unge mennesker, der dropper ud af skolen for at arbejde. Tages der højde for uregelmæssigheden i kontrolgruppen, forsvinder størstedelen af effekten fra reformen, og den endelige konklusion bliver således, at effekten af et ekstra års undervisningspligt er tvivlsom.

\section{Det tyske studie}

Studiet (Jasper et al., 2009) har til formål at identificere effektive tiltag rettet mod efterkvalificering af elever, der beskrives som ægte afbrydere.

Ægte afbrydere er en term, der bruges om unge, som enten helt falder fra en uddannelse uden at skifte til anden uddannelse, ender i ufaglærte jobs eller arbejdsløshed, eller når man ikke har kendskab til deres videre arbejds- eller uddannelsesforløb. Termen efterkvalificering bruges som en samlet betegnelse for eksisterende, aktuelle indsatser i form af støtteforanstaltninger/tiltag og programmer på forbunds- og landsniveau rettet mod frafaldselever. Disse tiltag og programmer har det overordnede sigte at fastholde elever på deres påbegyndte uddannelse eller at dirigere eleverne videre til anden uddannelse.

Studiet er udformet således, at det i første omgang kortlægges, hvilke indsatser der findes på forbunds- og landsniveau i Tyskland, og at disse dernæst analyseres med det overordnede ønske at udarbejde forbedringsforslag til at fastholde $x g$ te afbrydere på en erhvervsuddannelse eller støtte dem til at tage en anden erhvervsuddannelse.

Studiets resultater viser en række forbedringsforslag, der kan medvirke til at optimere og målrette uddannelsestilbuddene. Disse forbedringsforslag kan samles under tre overordnede temaer. (1) Forbedring af statistisk datagrundlag, (2) fortsættelse af erhvervsuddannelsesreformen og (3) netværk og vejledning. 


\section{(1) Forbedring af statistisk datagrundlag}

Studiet finder og problematiserer, at der i den eksisterende statistik på forbunds- og landsplan ikke skelnes mellem forskellige typer af frafald. I statistikkerne fremgår det ikke tydeligt, om der er tale om transfer-elever, dvs. elever, der afbryder en uddannelse for at læse videre på en anden, eller elever, der helt frafalder en uddannelse, og som ikke kommer i gang med en anden kompetencegivende uddannelse. Det anbefales derfor i studiet, at den eksisterende uddannelses- og videreuddannelsesstatistik suppleres med registrering af data om elevernes køn, etnicitet, afbrudt uddannelse/profession, og at den giver en nøje beskrivelse af grundene til uddannelsesafbrydelsen.

\section{(2) Fortsættelse af erhvervsuddannelsesreformen}

Studiet anbefaler, at man overvejer andre muligheder til at integrere frafaldselever i efterkvalificering og erhvervsarbejde. Det anbefales, at der forskes i alternative måder at tilegne sig erhvervskompetencer på udover den almindelige teori-praksisbaserede erhvervsuddannelsesform. Det anbefales, at andre uddannelsesmuligheder anerkendes og etableres som ligeværdige alternativer til den eksisterende, traditionelle erhvervsuddannelse. Derudover anbefales det, at antallet af virksomheder, der særligt er målrettet elever med indlæringsvanskeligheder under uddannelse, øges. Dertil er en forudsætning, at efterkvalificeringstiltagene er tilpasset virksomhedernes behov.

\section{(3) Netvark og vejledning}

Det er ifølge studiet vigtigt at udnytte og skabe overensstemmelse mellem de allerede eksisterende og tilgængelige vejlednings- og kvalificeringsstrukturer i forskellige delstater samt at samle disse i et samarbejdsnetværk på tværs af delstater.

I den forbindelse peger studiet på, at der bør etableres et netværk mellem aktører på forskellige ungdomserhvervsvejledningssteder på tværs af delstater. I forlængelse af dette påpeges det, at der ikke mangler tilbud til de unge i form af pædagogisk hjælp og andre tilbud om støtte, der specifikt er rettet mod ressourcesvage unge og unge med særlige indlæringsbehov ved overgangen fra grundskole til ungdomsuddannelse. Der mangler derimod sammenhæng mellem eksisterende tilbud på tværs af delstater, hvilket de forskellige professionel- 
le aktører kan rette op på ved at fungere som initiativtagere til at skabe den nødvendige kommunikation og samarbejde på tværs af de tyske delstater. Dertil nævnes, at det er nødvendigt med økonomisk støtte til at facilitere et sådant samarbejdsnetværk.

I forlængelse af dette opfordrer studiet til, at vejledningsindsatsen optimeres, ved (a) at der indføres opsøgende vejledning, idet ægte afbrydere oftest ikke kender til de eksisterende vejledningsmuligheder, og (b) at der indføres længerevarende vejledning, som er målrettet ressourcesvage elever og elever med indlæringsvanskeligheder, samt (c) at der etableres en kønstilpasset vejledning, der er målrettet vejledning af henholdsvis kvinder og mænd.

Det anbefales derudover, at de ægte afbryderes formelle og uformelle kompetencer systematisk vurderes og tages i betragtning, når det skal bestemmes hvilket tiltag, der er mest hensigtsmæssigt for den enkelte unge. Med formelle kompetencer menes de færdigheder, erfaringer og viden, som en frafaldselev allerede har tilegnet sig ved i kortere perioder at have været på en erhvervsuddannelse. Med uformelle kompetencer menes elevens personlige potentialer, der ligesom de formelle kompetencer analyseres gennem en slags 'potentialeanalyse', inden et tiltag sættes i gang. Når tiltaget forløber succesfuldt, skal det desuden være muligt for den unge at få et certifikat som bevis på den tilegnede viden og færdigheder.

Det anbefales derudover, at der generelt tages hensyn til forskellighederne mellem de ægte afbrydere, og i særdeleshed at der tages højde for deres etnicitet og køn, når det skal vurderes hvilket tiltag, der er mest oplagt. Det understreges i den forbindelse, at tilbuddene til de unge skal være udformet som både deltids-og fuldtidstilbud, som man kan vælge imellem, hvilket nødvendiggør, at der udarbejdes individuelle erhvervsudviklingsplaner (Berufsentwicklungspläne).

\section{Sammenfatning vedrørende frafald på erhvervsuddannelser}

Angående elev frafald på erhvervsuddannelserne peger resultaterne på flere faktorer: 
- Systemorienterede forklaringer: det lave antal lærere mindsker elevengagement, det manglende antal praktikpladser og det, at det er de stærkeste elever, der bliver hjulpet til praktikpladser, medfører frafald af de svageste elever

- Strategier mod frafald er individualiserede fremfor relateret til ændringer af uddannelsesmiljøerne og det sociale miljø

- Efter indførelsen af ungdomsarbejdsløshedspakken steg antallet af unge, der påbegyndte en ungdomsuddannelse, samtidig med at frafaldet på ungdomsuddannelserne steg

- Manglende praktikpladser - skolepraktikken afvises af såvel økonomiske som faglige grunde

- Støtte til elevers praktikpladssøgninger varierer fra lærer til lærer, fra fag til fag og fra skole til skole. Der ses en tendens til, at elever med stærke sociale netværk via familie og venner, er dem, der får en praktikplads

- Skoleledelse og lærerkompetencer spiller en stor rolle i forhold til frafald

- Værkstedsbaseret undervisning styrker både elevernes skolemæssige motivation og deres engagement

- Den obligatoriske kompetencevurdering kan af lærerne bruges til at frasortere de svageste eleverpå den måde, at lærerne "bortvejleder" nogle elever

- Unge, der vælger en erhvervsuddannelse ud fra en begrundelse om, at de er skoletrætte og ønsker at tjene penge, har større risiko for at frafalde uddannelsen

- Unge, der vælger en erhvervsuddannelse på baggrund positive erfaringer fra erhvervspraktik, faglige interesser og fremtidige beskæftigelsesmuligheder, har mindre frafald

- De interesser, unge har i forhold til deres kommende arbejdsliv, fremmer deres chancer for at gennemføre en erhvervsuddannelse

- Det har en positiv effekt på gennemførelsen af en erhvervsuddannelse, at eleverne har modtaget uddannelses- og erhvervsvejledning med fokus på job- og karrieremuligheder

- Frafald hænger også sammen med læringsmiljøet og arbejdsformen. Eleverne foretrækker lærerstyret tavleundervisning fremfor gruppearbejde 
uden tydelig mål. Dette gælder både for dygtige elever, som ikke føler, at gruppearbejde er fagligt udfordrende nok, og for de introverte og socialt udfordrede elever

- Flere elever falder fra under praktikopholdet grundet: Manglende overensstemmelse mellem forventninger og selve opholdet, manglende omsorg for eleven under praktikken og kravet om effektivitet, som eleverne kan have svært ved at leve op til

- Flere etniske minoritetsunge falder fra, da de har vanskeligt ved at få en praktikplads sammenlignet med etnisk danske unge, da virksomheder har en opfattelse af, at det er forbundet med ekstraomkostninger

- Flere etniske minoritetsunge falder fra deres uddannelse, da de oplever det faglige niveau for højt samtidig med, at de oplever fagene som teoritunge og enkelte fag som uvedkommende i forhold til den kommende profession

- Erhvervsuddannelserne består af korte og opsplittede forløb med mange muligheder for sammensætning af fag, hvilket af flere etniske minoritetsunge opleves som uoverskueligt

- Lærerne på erhvervsuddannelserne skal kvalificeres og have vilkår til at sætte ind overfor frafald i hverdagen

- Elever på erhvervsuddannelser har stort udbytte af ledelsesstrategiske tiltag især i forhold til inddragelse af forældre, lydhørhed mellem skolens ansatte og ledelsen, at skolens ledelse har forventninger til elevernes og lærernes præstationer i undervisningen, at ledelsen superviserer lærerne og løbende evaluerer på elevernes resultater

- Effekten af et ekstra års undervisningspligt (i Holland fra 17 til 18 år) er tvivlsom

- Tiltag, som er målrettet unge, der er frafaldet en erhvervsuddannelse, skal være udformet som både deltids- og fuldtidstilbud, der kan vælges imellem, og valgene skal bygge på individuelle erhvervsudviklingsplaner. 


\section{Opsummering}

Formålet med denne systematiske forskningskortlægning er at besvare et specifikt spørgsmål:

Hvilke politisk håndterbare forhold kan via en målrettet indsats gøre en forskel i forhold til elevoptag, elevfrafald og elevudbytte på erhvervsuddannelserne?

Målet er at afdække, hvilke politiske tiltag der kan iværksættes i forhold til at sikre et større elevoptag, et mindre elevfrafald og bedre resultater for elever på erhvervsuddannelserne. Resultaterne i denne systematiske forskningskortlægning er interessante på flere områder i forhold til politisk håndterbare forhold. I dette afsnit gives et indblik i nogle af de centrale resultater, som er uddraget fra de 27 studier.

Indledningsvis kan nævnes, at erhvervsuddannelsernes omdømme er noget, der med fordel kan styrkes. Det er et gennemgående tema i flere af studierne, et erhvervsuddannelserne opleves som mindre prestigefyldte end de gymnasiale uddannelser. Endvidere ses også, at flere oplever det som meget skelsættende at vælge karriere direkte efter grundskolen, og at gymnasiet opleves som et mere naturligt valg efter grundskolen.

En indsats, der med fordel kunne iværksættes, er en bedre vejledning af de unge i udskolingen. Der er behov for vejledere, som både har kendskab til, men også kundskab om, hvilke uddannelsesmuligheder der findes på erhvervsuddannelserne, samt hvilke erhvervsmuligheder der findes efter endt uddannelse. Det nævnes endvidere i flere studier, at de unge kan have svært ved at overskue de mange muligheder, der er for at sammensætte forskellige fag og retninger indenfor uddannelserne.

Tættere relationer mellem elever, lærere, oplæringslærer og forældre synes også at have en positiv effekt på at fastholde eleverne på erhvervsuddannelserne. 
Samarbejde på tværs mellem erhvervsskolen og praktikstedet, hvor alle parter ved, hvad der forventes af eleven, og der er udarbejdet en målsætning for forløbene, styrker elevernes gennemførelse af uddannelsen.

Det ses også i resultaterne, at elever med specifikke vanskeligheder ikke trives $\mathrm{i}$ et for individuelt tilrettelagt program, der minder om en specialpædagogisk indsats. Det fælles miljø er væsentligt for trivslen. Samtidig fremhæves, at en lærerstruktureret tavleundervisning foretrækkes frem for gruppearbejde, som de stærke elever finder for lidt fagligt udfordrende, og som eleverne med specifikke vanskeligheder kan finde udfordrende.

Manglen på praktikpladser er også et centralt problem i forhold til frafald på erhvervsuddannelserne. Skolepraktikken fravælges af mange af flere årsager, bl.a. en lavere prestige, manglende tro på, at de rigtige kompetencer erhverves, og en dårlige løn end i virksomhedspraktik. Dette er interessante resultater, da elever, der har været i skolepraktik, udtrykker tilfredshed med forløbet, og det ses, at den teoretiske del af praktikken bedre kan tilpasses den enkelte elevs forudsætninger. Set i sammenhæng med, at virksomhederne kan have svært ved at forpligte sig til længere forløb grundet bl.a. økonomiske og produktionsmæssige forhold, vil det være oplagt at styrke en kombination af de to praktikformer på erhvervsuddannelserne. Dette kunne endvidere være med til at støtte de to kulturer, eleverne bevæger sig i: en skolekultur og en arbejdskultur. 


\section{Forskningskarakteristik}

Dette kapitel giver en samlet karakteristik af forskningen om håndterbare forhold til gavn for fastholdelse, øget optag og forbedrede resultater i erhvervsuddannelserne. Fremstillingen er baseret på de genbeskrivelser og vurderinger, som medarbejdere i Clearinghouse har gennemført. Der redegøres nærmere for studiernes almene, reviewspecifikke samt metodisk/designmæssige karakteristika. Fremstillingen afsluttes med en behandling af studiernes forskningskvalitet.

\section{Almen karakteristik}

Der er søgt efter undersøgelser, som er publiceret på engelsk, tysk, dansk og svensk, og der inddrages forskning fra Danmark, Sverige, Tyskland, Holland og Schweiz. De undersøgelser, som indgår i analysen, anvender data indsamlet i landene som vist i tabel 4:

\begin{tabular}{lc} 
Unders $\emptyset$ gelsesland & Antal unders $\varnothing$ gelser \\
\hline Danmark & 22 \\
\hline Tyskland & 5 \\
Holland & 4 \\
Sverige & 2 \\
\hline Schweiz & 3 \\
\hline
\end{tabular}

Tabel 4: Inkluderede undersøgelser fordelt på de lande, hvor der indsamles data $(\mathrm{N}=36)$

Af de 36 undersøgelser, som indgår i kortlægningen, har 22 (61 \%) danske data, 5 (14\%) tyske data, 4 (11\%) hollandske data, 2 (6\%) svenske data og 3 (8\%) schweiziske data. Tabellen ovenfor viser således, at over halvdelen, 61 \% af un- 
dersøgelserne, er gennemført i Danmark. Den resterende andel undersøgelser fordeler sig nogenlunde jævnt mellem henholdsvis Tyskland, Holland, Sverige og Schweiz.

\section{Metodisk/designmœssig karakteristik}

I Tabel 5 vises de anvendte forskningsdesign i de 36 inkluderede undersøgelser. Flere undersøgelser anvender mere end ét design, hvorfor antallet af anvendte design (41) er større end antallet af undersøgelser (36).

\begin{tabular}{lc}
\hline Forskningsdesign & Antal unders $\varnothing$ gelser \\
\hline Aktionsforskning & 1 \\
Casestudie & 10 \\
Cross-sectional studie & 8 \\
$\begin{array}{l}\text { Eksperiment med ikke-randomiseret alloke- } \\
\text { ring til grupper (quasi-eksperiment) }\end{array}$ & 1 \\
Longitudinelt studie (kohorte) & 7 \\
Longitudinelt studie (andet) & 3 \\
Etnografisk studie & 3 \\
Analyse af sekundære data & 8 \\
\hline
\end{tabular}

Tabel 5: Forskningsdesign ( $N=41$ kodninger af undersøgelser; flere kodninger pr. undersøgelse er mulig)

Som det afspejles i Tabel 5, benytter de inkluderede undersøgelser en række forskellige forskningsdesign. Heraf udgør casestudier og longitudinelle studier i alt $48 \%$ af det samlede antal anvendte design. $20 \%$ af undersøgelser anvender cross-sectional design, det samme gælder for undersøgelser, som benytter sekundære data (typisk hentet fra nationale surveyprogrammer). De resterende $12 \%$ udgøres af etnografiske studier samt et enkelt ikke-randomiseret eksperiment og et enkelt aktionsforskningsdesign. Fordelingen af forskningsdesign er således nogenlunde jævn med en lille overvægt af casestudier og longitudinelle studier.

De anvendte metoder til dataindsamling kan ses i tabel 6: 


\begin{tabular}{lc}
\hline Dataindsamlingsmetoder & Antal undersøgelser \\
\hline Kvalitative metoder & 16 \\
Kvantitative metoder & 18 \\
Mixed Methods & 6 \\
Uoplyst & 1 \\
\hline
\end{tabular}

Tabel 6: Dataindsamlingsmetoder ( $N=41$ dataindsamlingsmetoder; flere kodninger pr. undersøgelse er mulig)

De 36 inkluderede undersøgelser anvender forskellige metoder til dataindsamling, og flere undersøgelser gør brug af mere end én metode. I den ovenstående Tabel 6 er billedet, at undersøgelserne er meget jævnt fordelt mellem kvalitative og kvantitative metoder, henholdsvis $39 \%$ og $44 \%$, mens et mindre antal undersøgelser (15\%) anvender mixed methods. I en enkelt undersøgelse bliver dataindsamlingsmetoden ikke oplyst.

\section{Reviewspecifik karakteristik}

I dette afsnit belyses de spørgsmål i kortlægningen, der specifikt er rettet mod den forskning om erhvervsuddannelserne, som vedrører elevoptag, elevfrafald og elevresultater. De inkluderede undersøgelser kan med andre ord have følgende tre formål (1) Optagelsesvalg: at undersøge, hvad der får unge til at vælge at søge ind på en erhvervsuddannelse, (2) Elevfrafald og fastholdelse: at undersøge, hvad der får flest unge til at gennemføre en erhvervsuddannelse, og (3) Elevudbytte og resultater: at undersøge, hvad der făr flest unge til at præstere optimalt i forbindelse med en erhvervsuddannelse.

Fordelingen af undersøgelsernes overordnede fokus fremgår af Tabel 7:

\begin{tabular}{lc}
\hline Overordnet fokus & Antal undersøgelser \\
\hline Optagelsesvalg & 11 \\
Elevfrafald og fastholdelse & 25 \\
Elevudbytte og resultater & 3 \\
\hline
\end{tabular}

Tabel 7: Undersøgelsernes overordnede fokus

( $N=39$ kodninger af undersøgelser; flere kodninger pr. undersøgelse er mulig) 
Det fremgår af tabellen, at $69 \%$ af de inkluderede undersøgelser har det overordnede formål at undersøge elevfrafald og fastholdelse på erhvervsuddannelserne, mens $30 \%$ af undersøgelserne har til formål at undersøge elevoptag. Kun $8 \%$ af undersøgelserne har til formål at undersøge elevudbytte. Ikke overraskende er der altså et overvejende fokus på frafald og fastholdelse i de inkluderede undersøgelser.

En karakteristik af, hvordan de inkluderede undersøgelser kan klassificeres i forhold til policy, kan ses i Tabel 8:

\begin{tabular}{lc}
\hline $\begin{array}{l}\text { Hvordan kan undersøgelsen klassificeres i } \\
\text { forhold til policy? }\end{array}$ & Antal undersøgelser \\
\hline Konsekvenser af eksisterende policy & 17 \\
Konsekvenser af politiske ændringer & 11 \\
Andet & 10 \\
\hline
\end{tabular}

Tabel 8: Undersøgelsernes klassificering

( $N=38$ kodninger af undersøgelser; flere kodninger pr. undersøgelse mulig)

Det fremgår af tabellen, at knap halvdelen (47 \%) af de inkluderede undersøgelser undersøger konsekvenser af eksisterende policy, mens $30 \%$ undersøger konsekvenser af politiske ændringer. $27 \%$ procent af de inkluderede undersøgelser undersøger dog noget andet, som for eksempel uddannelsesvalg.

\section{Vurdering af forskningskvalitet og evidensvœgt}

Som indledning til dette afsnit er det væsentligt at fastslå, at kvalitetsvurderingen af forskningens resultater og standard udelukkende tager udgangspunkt i de beskrivelser, der er fremført af forskerne selv i de dokumenter, som udgør hver enkel undersøgelse. Det betyder, at kvalitetsvurdering og bestemmelse af evidensvægt udelukkende forholder sig til og vurderes på baggrund af forskningens egen afrapportering. Der kan således ikke kommenteres på primærforskningens proces, forløb, analyse(r) og data udover, hvad der er blevet transparent fremlagt. Vurderingen af kvaliteten af de 36 inkluderede undersø- 
gelser er således alene baseret på de rapporter, bøger, tidsskriftsartikler og afhandlinger, som er publiceret om dem.

I første omgang vil der her blive set på undersøgelsernes generelle forskningskvalitet, dvs., i hvilken udstrækning en undersøgelse med et givent sigte er gennemført og afrapporteret efter alment gældende standarder for videnskabeligt arbejde. Derefter vil der blive bestemt en samlet evidensvægt for hvert af de 36 studier.

Tabel 9 viser svarene på spørgsmålene i EPPI-spørgerammen, som direkte anvendes til at vurdere studiernes forskningskvalitet. Herved gives et overblik over den generelle forskningskvalitet i forhold til afrapporteringsstandarder:

\begin{tabular}{|c|c|c|}
\hline Spørgsmål & Ja, antal studier & Nej, antal studier \\
\hline $\begin{array}{l}\text { Er konteksten for unders } \emptyset \text { gelsen tilstrækkeligt } \\
\text { beskrevet? }\end{array}$ & 35 & 1 \\
\hline Er unders $\emptyset$ gelsens formål klart afrapporteret? & 35 & 1 \\
\hline $\begin{array}{l}\text { Er der en tilstrækkelig beskrivelse af samplet } \\
\text { anvendt i unders } \varnothing \text { gelsen, samt af hvordan sam- } \\
\text { plet blev identificeret og rekrutteret? }\end{array}$ & 26 & 10 \\
\hline $\begin{array}{l}\text { Er der en tilstrækkelig beskrivelse af metoder } \\
\text { brugt til dataindsamling? }\end{array}$ & 32 & 4 \\
\hline $\begin{array}{l}\text { Er der en tilstrækkelig beskrivelse af metoder } \\
\text { anvendt til analyse af data? }\end{array}$ & 28 & 8 \\
\hline $\begin{array}{l}\text { Er undersøgelsen beskrevet med tilstrækkelig } \\
\text { transparens? }\end{array}$ & 32 & 4 \\
\hline $\begin{array}{l}\text { Undgår forfatterne selektionsbias i afrapporte- } \\
\text { ringen? (afrapporteres der om alle relevante } \\
\text { fund?) }\end{array}$ & 35 & 1 \\
\hline
\end{tabular}

Tabel 9: Undersøgelsernes generelle forskningskvalitet i forhold til afrapporteringsstandarder $(N=36)$

Tallene i tabellen ovenfor giver ikke umiddelbart anledning til bekymring, da forskningskvaliteten i undersøgelserne generelt er høj. Det gælder på tværs af dataindsamling, design, reliabilitet, validitet og dataanalyse. Undersøgelsernes beskrivelse af anvendelse af samplings- og dataindsamlingsmetoder samt dataanalyse er tilstrækkelig i henholdsvis $72 \%, 89 \%$ og $78 \%$ af undersøgelserne. 
Dertil fremgår det af tabellen, at $89 \%$ af undersøgelserne lever op til kravet om transparens, og hele 97 \% af undersøgelserne formår at undgå selektionsbias (systematiske fejl) i afrapporteringen.

I Tabel 10 nedenfor gives et overblik over kvalitetsvurderingen af den forskning, der bliver afrapporteret i de inkluderede undersøgelser:

\begin{tabular}{|c|c|c|c|}
\hline Spørgsmål & $\begin{array}{l}\text { Ja, i høj } \\
\text { grad, antal } \\
\text { studier }\end{array}$ & $\begin{array}{l}\text { Ja, i nogen } \\
\text { grad, antal } \\
\text { studier }\end{array}$ & $\begin{array}{l}\text { Nej, an- } \\
\text { tal studi- } \\
\quad \text { er }\end{array}$ \\
\hline $\begin{array}{l}\text { Var det valgte forskningsdesign helt passende til } \\
\text { besvarelse af undersøgelsens forskningsspørgs- } \\
\text { mål? }\end{array}$ & 27 & 9 & 0 \\
\hline $\begin{array}{l}\text { Er der gjort tilstrækkeligt fors } \varnothing \mathrm{g} \text { på at etablere } \\
\text { reliabilitet i forhold til dataindsamlingsmetoder? }\end{array}$ & 17 & 16 & 3 \\
\hline $\begin{array}{l}\text { Er der gjort tilstrækkeligt fors } \emptyset \mathrm{g} \text { på at etablere } \\
\text { reliabilitet i forhold til dataanalysemetoder? }\end{array}$ & 16 & 17 & 3 \\
\hline $\begin{array}{l}\text { Er der gjort tilstrækkeligt fors } \varnothing g \text { på at etablere } \\
\text { validitet i forhold til dataindsamlingsmetoder? }\end{array}$ & 18 & 15 & 3 \\
\hline $\begin{array}{l}\text { Er der gjort tilstrækkeligt fors } \emptyset \mathrm{g} \text { på at etablere } \\
\text { validitet i forhold til dataanalysemetoder? }\end{array}$ & 15 & 20 & 1 \\
\hline $\begin{array}{l}\text { Kan anvendt forskningsdesign og undersøgel- } \\
\text { sesmetode udelukke systematiske fejl (bias), } \\
\text { som kunne føre til alternative forklaringer på } \\
\text { undersøgelsens resultater? }\end{array}$ & 15 & 20 & 1 \\
\hline Behandles generaliserbarhed i unders $\varnothing$ gelsen? & 13 & NA & 23 \\
\hline $\begin{array}{l}\text { I lyset af ovenstående forhold er revieweren af } \\
\text { undersøgelsen uenig med forfatterne i unders } \emptyset \text { - } \\
\text { gelsens fund og konklusioner? }\end{array}$ & 1 & NA & 35 \\
\hline
\end{tabular}

Tabel 10: Kvalitetsvurderinger af afrapporteret forskning $(N=36)$

Heller ikke Tabel 10 giver umiddelbart anledning til bekymring i forhold til forskningskvalitet. Knap halvdelen af de inkluderede undersøgelser lever således i høj grad op til almene krav om reliabilitet i forhold til dataindsamlings- og dataanalysemetoder (henholdsvis $47 \%$ og $44 \%$ ), validitet i forhold til dataindsamlings- og dataanalysemetoder (henholdsvis $50 \%$ og $42 \%$ ) samt om at undgå bias (42 \%). Lægger man de undersøgelser, der lever op til disse kriterier "i 
nogen grad" til disse andele, viser tabellen, at $92 \%$ af undersøgelserne i høj eller nogen grad lever op til kravene om reliabilitet i forhold til dataindsamlingsog dataanalysemetoder. Det samme gør sig gældende for de undersøgelser, som i høj eller nogen grad lever op til kravene om validitet i forhold til dataindsamlingsmetoder (92\%), mens alle med undtagelse af en enkelt undersøgelse (97\%) i høj eller nogen grad lever op til kravene for validitet i forhold til dataanalysemetoder. Samme tendens kan observeres i forhold til spørgsmålet, hvorvidt undersøgelsens anvendte design og undersøgelsesmetode i høj eller nogen grad kan udelukke bias (97\%). Således lever kun en meget lille andel af de inkluderede undersøgelser slet ikke op til kriterierne.

Et centralt aspekt af forskning er generaliserbarhed, som i kvalitetsvurderingen besvares ud fra spørgsmålet: "Behandles generaliserbarhed i studiet?". Her kan det konstateres, at 23 af de inkluderede undersøgelser (64\%) enten ikke tager stilling til generaliserbarhed, eller at resultaterne ikke kan siges at være generaliserbare, mens 13 undersøgelser (36\%) behandler generaliserbarhed på forskellig vis.

I forhold til spørgsmålet om, hvorvidt revieweren var uenig med forfatterne om undersøgelsernes fund og konklusioner, viser tabellen, at dette kun er tilfældet i en enkel undersøgelse ( $2 \%$ ). Det vurderes også, at det valgte design i høj grad var velegnet til besvarelse af undersøgelsens forskningsspørgsmål i 75 $\%$ af de inkluderede undersøgelser.

Tabel 11 viser fordelingen af den samlede evidensvægt for alle 36 undersøgelser: 


\begin{tabular}{|c|c|c|c|}
\hline \multicolumn{4}{|l|}{ Evidensvægt } \\
\hline & $\begin{array}{c}\mathrm{H} \varnothing \mathrm{j} \\
\text { evidens }\end{array}$ & $\begin{array}{l}\text { Middel } \\
\text { evidens }\end{array}$ & $\begin{array}{c}\text { Lav } \\
\text { evidens }\end{array}$ \\
\hline $\begin{array}{l}\text { Evidens A: Når der tages højde for al kvalitetsvurde- } \\
\text { ring, hvor pålidelig er da undersøgelsen mht. at be- } \\
\text { svare unders } \varnothing \text { gelsens egne forskningsspørgsmål? }\end{array}$ & 14 & 19 & 3 \\
\hline $\begin{array}{l}\text { Evidens B: Hvor passende er undersøgelsens anvend- } \\
\text { te forskningsdesign og analyse til at besvare re- } \\
\text { viewspørgsmålet? }\end{array}$ & 17 & 13 & 6 \\
\hline $\begin{array}{l}\text { Evidens C: Hvor relevant er undersøgelsens særlige } \\
\text { fokus (begrebsmæssigt, kontekst, sample og målin- } \\
\text { ger) for besvarelse af reviewspørgsmålet? }\end{array}$ & 14 & 14 & 8 \\
\hline Evidens D: Samlet evidens & 12 & 15 & 9 \\
\hline
\end{tabular}

Tabel 11: Studiernes samlede evidensvægt $(\mathrm{N}=36)$

Den samlede evidens D fremkommer som en samlet vurdering af evidens A, B og C. Evidens A er vurderingen af, om undersøgelsen i sig selv er troværdig. Dette er baseret på en lang række forskningsmetodiske vurderinger af undersøgelsens kvalitet vurderet på undersøgelsens egne præmisser. Evidens B er vurderingen af, om undersøgelsen har et forskningsdesign og en analyse, der er relevant i forhold til nærværende kortlægning. Evidens $C$ er vurderingen af, om undersøgelsen i sit indholdsmæssige fokus (begreber, kontekst, sampling) er relevant for det aktuelle reviewspørgsmål. Evidens D er den samlede vurdering af en undersøgelses evidens. Evidens A til evidens D er i forskningskvalitetsvurderingen forbundet med tre niveauer: En lav evidensvægt, en middel evidensvægt eller en høj evidens.

I denne kortlægning viser resultatet af forskningsvurderingerne, at $33 \%$ af de inkluderede undersøgelser har samlet høj evidensvægt, $42 \%$ har en samlet middel evidensvægt, og $25 \%$ af undersøgelserne har en samlet lav evidensvægt.

Da der ikke kan fæstes lid til resultaterne i de ni undersøgelser med en samlet lav evidensvægt, kan de ikke bruges til at besvare reviewspørgsmålet om, hvilke politisk håndterbare forhold der kan, via en målrettet indsats, gøre 


\section{2}

FORSKNINGSKORTL/EGNING AF HÅNDTERBARE FORHOLD TIL GAVN FOR FASTHOLDELSE, ØGET OPTAG OG FORBEDREDE RESULTATER I

ERHVERVSUDDANNELSERNE

en forskel i forhold til elevoptag, elevfrafald og elevudbytte på erhvervsuddannelserne. De øvrige 27 undersøgelser indgår i besvarelsen af reviewspørgsmålet. 


\section{Litteraturliste}

DEA (2013). De dårligste elever vælger en erhvervsuddannelse. Tænketanken DEA.

Gough, D., Oliver, S., \& Thomas, J. (2012). An introduction to systematic reviews. London: SAGE Publications.

Pihl, Mie Dalskov (2013). En erhvervsuddannelse betaler sig tilbage til samfundet fra dag ét. Arbejderbevægelsens Erhvervsråd. 


\section{Referenceliste over inkluderede studier}

\section{Sekundœre referencer er markeret med stjerne}

Albæk, K. (2005). Om lærepladsspørgsmålet. Nationaløkonomisk tidsskrift, 143, 125.

Andersen, D. (2005). 4 år efter grundskolen. 19-årige om valg og veje i ungdomsuddannelserne. København: AKF.

Becker, C., Gehrke, J., Anne Meyer, A., \& Schank, C. (2010). Evaluation des Pilotprojektes "3. Weg in der Berufsausbildung in NRW". Abschlussbericht. Im Auftrag des Ministeriums für Arbeit, Integration und Soziales des Landes NRW. Gesellschaft für innovative Beschäftigungsförderung.

Beer, D., \& Ternes, E. (2008). Analysen zur Situation und zum Verbleib der an BUS beteiligten Schülerinnen und Schüler. Ergebnisbericht zur Befragung der Lehrkräfte der BUS-Klassen 2005/2006. Bottrop: Gesellschaft für innovative Beschäftigungsförderung.

Cabus, S. J., \& De Witte, K. (2011). Does School Time Matter? - On the Impact of Compulsory Education Age on School Dropout. Economics of Education Review. 30, 1384-1398.

Danmarks Evalueringsinstitut (2009). Frafald på grundforløbet på de merkantile erhvervsuddannelser. København: Danmarks Evalueringsinstitut.

Danmarks Evalueringsinstitut (2011). Evaluering af forsøg med erhvervsklasser. København: Danmarks Evalueringsinstitut.

Danmarks Evalueringsinstitut (2011). Skolepraktik i erhvervsuddannelserne. København: Danmarks Evalueringsinstitut. 
Danmarks Evalueringsinstitut (2012). 10. klasse - på vej mod ungdomsuddannelse. Anden del af evalueringen af 10. klasse. København: Danmarks Evalueringsinstitut.

Danmarks Evalueringsinstitut (2013). At falde fra eller til. Frafaldsanalyse for SOPU. København: Danmarks Evalueringsinstitut.

Danmarks Evalueringsinstitut (2013). Studenter i erhvervsuddannelserne. En undersøgelse af gymnasiale dimittenders valg og veje gennem uddannelsessystemet. København: Danmarks Evalueringsinstitut.

Elffers, L., Oort, F. J., \& Karsten, S. (2012). Making the Connection: The Role of Social and Academic School Experiences in Students' Emotional Engagement with School in Post-Secondary Vocational Education. Learning and Individual Differences, 22, 242-250.

Espersen, L. D., Eiberg, M., \& Andersen, D. (2011). Veje til Ungdomsuddannelse 2. Kvalitative interview med skoleledere, lærere, elever og UU-vejledere. København: SFI.

Glaesser, J. (2006). Dropping Out of Further Education: A Fresh Start? Findings from a German Longitudinal Study. Journal of Vocational Education and Training, 58, 83-97.

Grønborg, L. (2011). Fastholdelse igennem idræt og sundhed. I: C. H. Jørgensen (Red.), Frafald i erhvervsuddannelserne (s. 49-66). Frederiksberg: Roskilde Universitetsforlag.

Grønborg, L. (2013). One of the boys: constructions of disengagement and criteria for being a successful student. International Journal of Qualitative Studies in Education, 26(9), 1192-1209.

*Hall, C. (2009). Does making upper secondary school more comprehensive affect dropout rates, educational attainment and earnings? Evidence from a Swedish pilot scheme. Uppsala: Institute for Labour Market Policy Evaluation.

Hall, C. (2012). The Effects of Reducing Tracking in Upper Secondary School: Evidence from a Large-Scale Pilot Scheme. Journal of Human Resources, 47, 237 269.

Hofman, W. H. A., \& Hofman, R. H. (2011). Smart Management in Effective Schools: Effective Management Configurations in General and Vocational Education in the Netherlands. Educational Administration Quarterly, 47, 620-645. 
Jasper, G., Richter, U. A., Haber, I., \& Vogel, H. (2009). Ausbildungsabbrüche vermeiden - neue Ansätze - und Lösungsstrategien. Band 6 der Reihe Berufsbildungsforschung. Bonn: Bundesministerium für Bildung und Forschung.

Jensen, T. P., \& Larsen, B. Ø. (2011). Unge i erhvervsuddannelserne og på arbejdsmarkedet. Værdier, interesser og holdninger. København: AKF.

Jensen, U. H., \& Hansen, F. S. (2006). Etniske minoritetsunge i Roskilde-hvem er de og hoad kan der gøres for at flere får en uddannelse?. København: Forskningsenheden i Vejledning, Danmarks Pædagogiske Universitet.

Jensen, U. H., \& Jensen, T. P. (2005). Unge uden uddannelse. Hvem er de, og hvad kan der gøres for at få dem i gang?. København: SFI.

Jensen, U. H., \& Jørgensen, B. T. (2005). Baggrundsrapport I. "Det vigtigste i livet er at få en uddannelse" - undersøgelse af etniske minoritetsunges frafald fra erhvervsuddannelserne. København: AKF.

Jonker, E. F. (2006). School Hurts: Refrains of Hurt and Hopelessness in Stories about Dropping out at a Vocational School for Care Work. Journal of Education and Work, 19, 121-140.

Jørgensen, C. H. (2011). Praktikpladsproblemets betydning for elevernes frafald og engagement. In C. H. Jørgensen (Red.), Frafald i erhvervsuddannelserne (s. 185-204). Frederiksberg: Roskilde Universitetsforlag. Frafald i erhvervsuddannelserne.

Jørgensen, C. H., Jensen, H. H., Larsen, L., \& Hansen, J. A. (2006). Hvorfor oprettes der ikke praktikpladser? En undersøgelse indenfor fire uddannelser: $\mathrm{Mu}$ rer, automatikfagtekniker, kontor og social- og sundhedsassistent. Roskilde: Institut for Uddannelsesforskning, Roskilde Universitetscenter.

*Jørgensen, C. H., Koudahl, P., Nielsen, K., \& Tanggaard, L. (2012). Frafald og engagement: Foreløbige resultater. Den kvalitative del.

Kammermann, M., Stalder, B. E., \& Hättich, A. (2011). Two-Year Apprenticeships - A Successful Model of Training?. Journal of Vocational Education and Training, 63(3), 377-396.

Katznelson, N. (2007). De måske egnede på erhvervsuddannelserne - om frafald og fastholdelse af udsatte unge. Odense: Erhvervsskolernes Forlag. *Larsen, B. Ø., \& Jensen, T. P. (2010). Fastholdelse af elever på de danske erhvervsskoler. København: AKF. 
Laursen, D. N., \& Nielsen, K. (2009). Fuldførelse, fastholdelse og frafald. En analyse af 'best practice' i praktikken. Århus: Aarhus Universitet, Psykologisk Institut.

*Müller, B., \& Schweri, J. (2006). Die Entwicklung der betrieblichen Ausbildungsbereitschaft. Eine Längsschinttuntersuchung zur dualen Berufsbildung in der Schweiz (Schriftenreihe Nr. 31). Zollikofen: Schweizerisches Institut für Berufspädagogik.

Müller, B., \& Schweri, J. (2007). Why has the share of training firms declined in Switzerland. Zeitschrift für Arbeitsmarktforschung, 40, 149-167.

*Nielsen, K., \& Jørgensen, C. H. (2013). Frafald, omvalg eller fravalgt?. Dansk Prdagogisk Tidsskrift nr. 3, 86-96.

Nielsen, K., Jørgensen, C. H., Koudahl, P., Munk, M. D., Jensen, T. P., Pedersen, L. T., ... \& Lippke, L. (2013). Slutrapport: Erhvervsskoleelever i det danske erhvervsuddannelsessystem. Århus.

Pless, M., \& Katznelson, N. (2005). Niende klasse og hvad så? - en midtvejsrapport om unges uddannelsesvalg og overgang fra grundskole til ungdomsuddannelse og arbejde. København: Center for Ungdomsforskning.

Stern, S., Marti, C., von Stokar, T., \& Ehrler, J. (2010). Evaluation der zweijährigen beruflichen Grundbildung mit EBA. Schlussbericht. Lausanne: Institut de hautes etudes en administration publique.

Tanggaard, L. (2013). An exploration of students' own explanations about dropout in vocational education in a Danish context. Journal of Vocational Education E Training, 65(3), 422-439.

Uhly, A., Kroll, S., \& Krekel, E. M. (2011). Strukturen und Entwicklungen der zweijährigen Ausbildungsberufe des dualen Systems. Ergebnisse aus der Berufsbildungsstatistik der statistischen Ämter des Bundes und der Länder (Erhebung zum 31.12.) sowie der BIBB-Erhebung über neu abgeschlossene Ausbildungsverträge zum 30. 09. Bonn: Bundesinstitut für Berufsbildung.

Åteg, M. (2005). Attraktiv industriutbildning på gymnasiet: Ett deltagandeperspektiv på lokalt utvecklingsarbete. Arbetsliv i omvandling, 2, 1-110. 


